\title{
Measurements of the aerosol chemical composition and mixing state in the Po Valley using multiple spectroscopic techniques
}

\author{
S. Decesari ${ }^{1}$, J. Allan ${ }^{2}$, C. Plass-Duelmer ${ }^{3}$, B. J. Williams ${ }^{4,5}$, M. Paglione ${ }^{1}$, M. C. Facchini ${ }^{1}$, C. O'Dowd ${ }^{6}$, \\ R. M. Harrison ${ }^{7,9}$, J. K. Giett ${ }^{7,3}$, H. Coe ${ }^{2}$, L. Giulianelli ${ }^{1}$, G. P. Gobbi ${ }^{1}$, C. Lanconelli ${ }^{1}$, C. Carbone ${ }^{1}$, D. Worsnop ${ }^{4}$, \\ A. T. Lambe $^{4}$, A. T. Ahern ${ }^{4, * *}$, F. Moretti ${ }^{8}$, E. Tagliavini ${ }^{8}$, T. Elste ${ }^{3}$, S. Gilge $^{3}$, Y. Zhang ${ }^{5}$, and M. Dall'Osto ${ }^{6, *}$ \\ ${ }^{1}$ Institute of Atmospheric Sciences and Climate of the National Research Council of Italy (ISAC-CNR), Bologna, Italy \\ ${ }^{2}$ School of Earth, Atmospheric and Environmental Science, University of Manchester, Manchester, UK \\ ${ }^{3}$ Deutscher Wetterdienst (DWD), Meteorological Observatory, Hohenpeissenberg, Germany \\ ${ }^{4}$ Aerodyne Research, Inc., Billerica, MA, USA \\ ${ }^{5}$ Energy, Environmental and Chemical Engineering, Washington University in St. Louis, St. Louis, MO, USA \\ ${ }^{6}$ School of Physics, National University of Ireland, Galway, Ireland \\ ${ }^{7}$ School of Geography, Earth and Environmental Sciences, University of Birmingham, Birmingham, UK \\ ${ }^{8}$ Centro Interdipartimentale di Ricerca per le Scienze Ambientali, University of Bologna, Bologna, Italy \\ ${ }^{9}$ Department of Environmental Sciences/Center of Excellence in Environmental Studies, King Abdulaziz University, \\ P.O. Box 80203, Jeddah, 21589, Saudi Arabia \\ * now at: Institut de Ciències del Mar, CSIC, Barcelona, Spain \\ *** now at: Center for Atmospheric Particle Studies, Carnegie Mellon University, Pittsburgh, PA, USA
}

Correspondence to: S. Decesari (s.decesari@isac.cnr.it)

Received: 6 March 2014 - Published in Atmos. Chem. Phys. Discuss.: 4 April 2014

Revised: 12 September 2014 - Accepted: 30 September 2014 - Published: 18 November 2014

\begin{abstract}
The use of co-located multiple spectroscopic techniques can provide detailed information on the atmospheric processes regulating aerosol chemical composition and mixing state. So far, field campaigns heavily equipped with aerosol mass spectrometers have been carried out mainly in large conurbations and in areas directly affected by their outflow, whereas lesser efforts have been dedicated to continental areas characterised by a less dense urbanisation. We present here the results obtained at a background site in the Po Valley, Italy, in summer 2009. For the first time in Europe, six state-of-the-art spectrometric techniques were used in parallel: aerosol time-of-flight mass spectrometer (ATOFMS), two aerosol mass spectrometers (high-resolution time-of-flight aerosol mass spectrometer HR-ToF-AMS and soot particle aerosol mass spectrometer - SP-AMS), thermal desorption aerosol gas chromatography (TAG), chemical ionisation mass spectrometry (CIMS) and (offline) proton nuclear magnetic resonance $\left({ }^{1} \mathrm{H}-\mathrm{NMR}\right)$ spectroscopy. The results indicate that, under high-pressure conditions, atmospheric stratification at night and early morn-
\end{abstract}

ing hours led to the accumulation of aerosols produced by anthropogenic sources distributed over the Po Valley plain. Such aerosols include primary components such as black carbon (BC), secondary semivolatile compounds such as ammonium nitrate and amines and a class of monocarboxylic acids which correspond to the AMS cooking organic aerosol (COA) already identified in urban areas. In daytime, the entrainment of aged air masses in the mixing layer is responsible for the accumulation of low-volatility oxygenated organic aerosol (LV-OOA) and also for the recycling of non-volatile primary species such as black carbon. According to organic aerosol source apportionment, anthropogenic aerosols accumulating in the lower layers overnight accounted for $38 \%$ of organic aerosol mass on average, another $21 \%$ was accounted for by aerosols recirculated in residual layers but still originating in northern Italy, while a substantial fraction $(41 \%)$ was due to the most aged aerosols imported from transalpine areas. The different meteorological regimes also affected the BC mixing state: in periods of enhanced stagnation and recirculation of pollutants, the number fraction 
of the BC-containing particles determined by ATOFMS was $75 \%$ of the total, while in the days of enhanced ventilation of the planetary boundary layer (PBL), such fraction was significantly lower $(50 \%)$ because of the relative greater influence of non-BC-containing aerosol local sources in the Po Valley. Overall, a full internal mixing between $\mathrm{BC}$ and the nonrefractory aerosol chemical components was not observed during the experiment in this environment.

\section{Introduction}

Mass spectrometry of atmospheric aerosol (MSAA) has recently been established and has quickly become the most essential and fastest growing area of aerosol research (Laskin et al., 2012). Such techniques have greatly enhanced our capacity for observing the atmospheric processes responsible for the formation and evolution of airborne particles. However, currently none of the MSAA instruments is ideal in terms of both recovery and identification level because the individual techniques differ in terms of sensitivity towards specific aerosol components. Hence, the use of co-located complementary spectroscopic methods has become a prerequisite for large field experiments dealing with ambient aerosol chemical characterisation. In recent years, several of such experiments took place within or in the proximity of megacities and other large metropolitan areas: MILAGRO in Mexico City (Doran et al., 2007), SOAR and CalNex in Los Angeles (Docherty et al., 2008; Hayes et al., 2013), REPARTEE and ClearfLo in London (Harrison et al., 2012; Young et al., 2014), MEGAPOLI in Paris (Healy et al., 2013), SAPUSS in Barcelona (Dall'Osto et al., 2013). Alternatively, supersites were located in rural areas but still with the aim of characterising the export of pollutants from very large conurbations such as the New York area (NEAQS-ITCT; Fehsenfeld et al., 2006). Less attention has been paid to land sites where urbanisation is less dense and urban, agricultural and (semi)natural lands are intermingled in complex mosaics, which is a common situation for many continental areas. In Europe, for instance, the total number of inhabitants of the five megacities (Istanbul, Moscow, London, Paris, Rhine-Ruhr) accounts for only $11 \%$ of the total urban population in the continent (ca. 550 millions, source: United Nations Environment Programme - UNEP). The experimental strategy of intercepting pollution plumes and linking aerosol characteristics to transport time, which proved to be successful in metropolitan areas and in downwind areas, cannot work for aerosol studies at supersites surrounded by complex patterns in land use and emission types. We present here the results obtained in the Po Valley in summer 2009 during an intensive field campaign organised in the frame of the European Integrated Project on Aerosol Cloud Climate and Air Quality Interactions (EUCAARI) project (Kulmala et al., 2011). The Po Valley has 20 million inhabitants but is spread over an area of $48000 \mathrm{~km}^{2}$. Urbanisation is more dense in the northern sector of the valley and extended areas of mainly agricultural land are found in the central and south-east sectors. The station where the field campaign took place, San Pietro Capofiume (SPC), is located in the middle of such a periphery of the Po Valley, in a sparsely populated, flat rural area in the south-east part of the valley. It is recognised that the Po Valley is a major European pollution hotspot due to a high intensity of anthropogenic sources and to the orography which can limit atmospheric dispersion of pollutants. Nevertheless, the actual impacts of specific sources and of atmospheric dynamics are expected to vary considerably during the year in an area characterised by hot and dry summers and moderately cold winters. In previous papers (Saarikoski et al., 2012; Paglione et al., 2014), we showed that aerosol concentration and chemical composition in the rural Po Valley during late winter and early spring are governed by a reduced vertical mixing in the low troposphere, accumulating combustion particles and secondary aerosols in the low altitude levels. Contrasting dynamics are found in the summer, when the atmosphere is very convective with mixing layer height normally reaching $1500-2000 \mathrm{~m}$ above the ground (Di Giuseppe et al., 2012), making the Apennine ridge on the southern border of the valley a permeable barrier for extended transport. To the north of the Po Valley, Henne et al. (2004) have shown that aerosol-rich boundary layer air lifted by thermally driven valley breezes can cross the Alps mountain system. This means that in principle the Po Valley cannot be considered a closed system during the summer season. In previous studies in the area, observations of aerosol chemical composition were carried out with traditional samplers coupled with offline analyses (Carbone et al., 2010). A major limitation of the offline analyses is that, due to the poor time resolution (12-24h), they can observe variations in aerosol chemical composition over timescales which are much longer than those typical of the meteorology. Here, we employ modern spectroscopic aerosol instrumentation to investigate for the first time aerosol concentration and composition at a background site during the summertime in the Po Valley (from 28 June to 12 July 2009) at high time resolution $(1 \mathrm{~h})$. We investigate secondary organic aerosol production, nitrate production and source apportionment of organic aerosol. The experiment can be considered representative of other heavily populated areas characterised by a dry summer, intense photochemistry and by quasi-permanent summer mesoscale circulations driven by land-sea contrasts or by a complex orography, which is a common situation in subtropical areas of Eurasia and North America. 


\section{Methodology}

\subsection{Measurement site and meteorological measurements}

San Pietro Capofiume (SPC; $44.23^{\circ} \mathrm{N}, 11.22^{\circ} \mathrm{E} ; 11 \mathrm{~m}$ a.s.l.) is a rural background site (distance from major pollution sources: 10-50 km; Larssen et al., 1999) in the south-eastern Po Valley. Micro-meteorological measurements included determination of temperature, relative humidity, wind intensity and direction and precipitation which were measured in continuous mode at $6 \mathrm{~m}$ above the ground using a WXT510 (Vaisala) station. Atmospheric aerosol vertical profiling was provided by a commercial lidar ceilometer, Vaisala LD-40 working with a $855 \mathrm{~nm}$ laser. In addition to aerosol loads, signal analysis allowed tracking of the PBL evolution by using aerosols as markers (Di Giuseppe et al., 2012). Vertical profiles of temperature, humidity and wind intensity and directions were directly obtained also by radiosondes launched once per day, at 00:00 UTC.

\subsection{Gas-phase composition}

Concentrations of ozone were furnished by the EmiliaRomagna monitoring network for atmospheric pollution. Gaseous sulfuric acid and $\mathrm{OH}$ radicals were measured by Deutscher Wetterdienst (DWD) chemical ionisation mass spectrometry (CIMS) as previously described by Berresheim et al. (2000), Rohrer and Berresheim (2006) and PlassDülmer et al. (2011). The instrument was set up in a container and sampled air from a height of $3 \mathrm{~m}$ above ground, $0.5 \mathrm{~m}$ above the container. The system has a sensitivity of $2 \times 10^{5}$ sulfuric acid molecules $\mathrm{cm}^{-3}$ and an estimated accuracy of $30 \%$. In addition to sulfuric acid, also malonic acid (MA) and methanesulfonic acid (MSA) are ionised by nitrate ions and detected at the corresponding ionised acid masses in the DWD CIMS. Though several attempts were undertaken to directly calibrate these compounds from vaporised mixtures, no reliable calibration was achieved. Consequently, we used as a rough estimate the same calibration factor for MA and MSA as for $\mathrm{H}_{2} \mathrm{SO}_{4}$ in this paper.

Furthermore, during the campaign $\mathrm{SO}_{2}$ was measured by a fluorescence sensor (Thermo, TE $43 \mathrm{~S}$ ), NO by chemiluminescence with $\mathrm{O}_{3}$ (ECO-Physics CLD 770AL ppt), and $\mathrm{NO}_{2}$ by photolytic conversion (ECO-Physics) and measurement as NO (Gilge et al., 2010). Finally, photolysis frequencies of $\mathrm{NO}_{2}$ and ozone to yield $J\left(\mathrm{O}^{1} \mathrm{D}\right)$ were measured by sets of up and downward looking filter radiometers (MetCon).

\subsection{Offline aerosol chemical determinations}

The size distribution of the main aerosol chemical compounds was measured using 5-stage Berner impactors and offline chemical analysis (Matta et al., 2003). Daytime and night-time samples were collected separately every $12 \mathrm{~h}$ with substrates changed at 09:00 and 21:00 LT (local time)
(08:00 and 20:00 UTC + 1). The substrates were extracted with deionised water and analysed by ion chromatography, total organic carbon (TOC) analysis and nuclear magnetic resonance (NMR) spectroscopy. Anions were separated and quantified on a Dionex ICS-2000 ion chromatograph, equipped with an IonPac AS11 $2 \times 250 \mathrm{~mm}$ Dionex separation column. A second separation column (IonPac CS16 $3 \times 250 \mathrm{~mm}$ Dionex) was used for the analysis of inorganic cations and organic bases (methyl-, dimethyl-, trimethyl-, ethyl- and diethyl-ammonium). Water-soluble organic carbon (WSOC) was determined using a nitrogen and carbon analyser Analytik Jena Multi N/C 2100S (Rinaldi et al., 2007). Total carbon (TC) was measured using the solidmodule of the same elemental analyser.

Functional group characterisation was performed by proton nuclear magnetic resonance $\left({ }^{1} \mathrm{H}-\mathrm{NMR}\right)$ spectroscopy. $\mathrm{PM}_{1}$ samples were collected separately for daytime and night-time conditions (changing the filters at 09:00 and 21:00 LT). Spectra of aerosol WSOC were recorded at $600 \mathrm{MHz}$ with a Varian Inova 600 spectrometer. From 400 to 800 scans were acquired for each spectrum depending on the concentration. The HOD peak was suppressed by presaturation using a PRESAT pulse sequence. A $1 \mathrm{~Hz}$ line broadening (LB) weighting function and baseline correction was applied. After processing the spectra, a $0.03 \mathrm{ppm}$ binning on the chemical shift was applied to generate the matrix of data for factor analysis. The integrals of the spectra were set to the total NMR concentrations as $\mu \mathrm{molH} \mathrm{m}{ }^{-3}$ for the specific samples. Finally, bins containing peaks from blanks were removed. The resulting matrix dimension was $28 \mathrm{sam}-$ ples $\times 186$ points (NMR chemical shift bins). Factor analysis for spectral deconvolution was performed using a sub-set of the algorithms introduced in a previous publication (Decesari et al., 2011); that is, EPAv3.0 PMF (positive matrix factorisation; Paatero and Tapper, 1994), NMF (non-negative matrix factorisation) employing a projected gradient boundconstrained optimisation (Lin, 2007), and MCR (multivariate curve resolution) using the alternating least square method (MCR-ALS; Tauler, 1995; Jaumot et al., 2005). The uncertainty of the measurements for PMF was calculated as three times the baseline noise on the binned spectra.

\subsection{Online aerosol mass spectrometric measurements}

The aerosol time-of-flight mass spectrometer (ATOFMS) collects bipolar mass spectra of individual aerosol particles. Ambient aerosol is focused into a narrow particle beam for sizes between $100 \mathrm{~nm}$ and $3 \mu \mathrm{m}$. Using a two-laser velocimeter, particle aerodynamic sizes are determined from particle velocity after acceleration into the vacuum. In addition, the light scattered by the particles is used to trigger a pulsed high power desorption and ionisation laser $(\lambda=266 \mathrm{~nm}$, about $1 \mathrm{~mJ}$ pulse ${ }^{-1}$ ) which evaporates and ionises the particle in the centre of the ion source of a bipolar reflectron ToFMS. Thus, 
a positive and negative ion spectrum of a single particle are obtained (Gard et al., 1997).

The Aerodyne high-resolution time-of-flight aerosol mass spectrometer (HR-ToF-AMS) (DeCarlo et al., 2006; Canagaratna et al., 2007) focuses aerosol particles in the size range $50-600 \mathrm{~nm}$ onto a hot surface $\left(\right.$ at $600{ }^{\circ} \mathrm{C}$ ) using an aerodynamic lens assembly (Jayne et al., 2000). The instrument provides quantitative mass loading information on nonrefractory components using a well-characterised series of calibrations and error estimations (Jimenez et al., 2003; Allan et al., 2003, 2004; Drewnick et al., 2005). The HR-ToFAMS was deployed in the standard configuration, taking both mass spectrum (MS) and particle time of flight (pToF) data. The MS mode was run in $\mathrm{V}$-mode with a mass resolution of up to $3000 \mathrm{~m} / \Delta \mathrm{m}$ alternatively with a $\mathrm{W}$-mode, which increases resolution to $6000 \mathrm{~m} / \Delta m$ but decreases sensitivity by approximately 1 order of magnitude. The instruments were calibrated using $350 \mathrm{~nm}$ monodisperse ammonium nitrate particles and based on previous experience in urban environments, a collection efficiency (CE) of 0.5 was estimated based on the parameterisation proposed by Middlebrook et al. (2012).

The soot particle aerosol mass spectrometer (SP-AMS) makes real-time, in situ measurements of black carboncontaining particles (Onasch et al., 2012). By using an active Nd:YAG $(1064 \mathrm{~nm})$ laser cavity in place of the tungsten vaporiser, the SP-AMS uses laser-induced incandescence of absorbing soot particles to vaporise both the coatings and elemental carbon cores within the ionisation region of the AMS, providing a unique and selective method for measuring the mass of the refractory carbon cores (i.e. black carbon mass), the mass and chemical composition of any coating material (e.g. organics, sulfates, nitrates), and particle size and morphology. The data presented here are not absolutely quantitative because at the time of the experiment, a calibration protocol had not been developed; however, the temporal trends should still be accurate.

The high-resolution time-of-flight mass spectrometer thermal desorption aerosol gas chromatograph (HR-ToFMSTAG) system provides hourly speciated organic aerosol composition. Fine particles are inertially impacted into a collection and thermal desorption (CTD) cell, then desorbed into a gas chromatograph for chemical separation and finally delivered to an electron ionisation HR-ToFMS for compound identification and quantification. This was the first field deployment of a TAG system (Williams et al., 2006) adapted to a TofWerk HR-ToFMS detector, which later led to the development of a combined TAG-AMS (Williams et al., 2014). During operation at SPC, the HR-ToFMS-TAG incorporated a custom heated transfer line between the gas chromatograph (GC) and ToFMS, and a high pass quadrupole filter to eliminate carrier gas (helium) ions prior to ToFMS detection. TAG chromatograms were processed by PMF analysis using a novel chromatogram binning technique (Zhang et al., 2014).

\subsection{Black carbon measurements}

A single wavelength particle soot absorption photometer (PSAP, Radiance Research) was used to measure the aerosol volume absorption coefficient $\sigma_{\mathrm{a}}$ at $573 \mathrm{~nm}$, through a filterbased technique (Bond et al., 1999; Virkkula et al., 2005). Black carbon (BC) mass concentrations were calculated assuming a mass absorption cross section (MAC) of $10 \mathrm{~m}^{2} \mathrm{~g}^{-1}$ (Zanatta et al., 2014). The exact MAC, as well as its variability during the campaign, are unknown. On the other hand, the comparison between the PSAP and the SP-AMS results supports a relative stability of the MAC value during the campaign (see the discussion below).

\section{Results}

\subsection{Air mass classification and planetary boundary layer (PBL) meteorology}

July 2009 was wetter and colder than the average July conditions and no heat waves were observed during the measurement campaign. The experiment is therefore more representative of background conditions in the Po Valley in the summer, and does not account for high temperature anomalies. According to air mass classification based on HYSPLIT (Hybrid Single Particle Lagrangian Integrated Trajectory) backtrajectory cluster analysis (Fig. S1 in the Supplement, Table S1 in the Supplement), the conditions encountered during the Po Valley, 2009 field study can be summarised in three periods: (1) continental air masses with a high residence time ( $\geq 24 \mathrm{~h}$ ) in the Po Valley (PoV-type trajectories) prevailed during the first week of campaign. (2) An outbreak of westerly (Atlantic, west-type trajectories) air masses was observed between 8 and 9 July. Finally, (3) a partial recovery of more stable conditions characterised the last two days, with continental air masses travelling from east-northeast (PoV ENE type).

The diurnal cycle of the atmospheric boundary layer (PBL) was monitored by following the changes in the vertical aerosol extinction measured by the ceilometer (Di Giuseppe et al., 2012; Fig. S2) and by means of simple chemical tracers. In particular, the observed anticorrelation between the concentrations of $\mathrm{NO}_{\mathrm{x}}$ and of ozone (Fig. S3) points to a classical evolution of the PBL for continental areas: a stably stratified atmosphere lasts overnight causing $\mathrm{NO}_{\mathrm{x}}$ accumulation and ozone destruction by deposition and by $\mathrm{NO}_{\mathrm{x}}$ titration; in morning hours a thick, turbulent mixing layer develops and is accompanied by the entrainment of ozone-rich residual layers (Kleinman et al., 1994; Deserti et al., 2010). The morning transition usually occurred at 09:00-10:00 LT.

The ceilometer profiles indicate that the entrainment of aerosol-rich residual layers frequently occurred in the periods of high-pressure conditions during the campaign. Interestingly, following the onset of stagnant conditions around 
29-30 June, the aerosol scattering in the residual layers became progressively more intense, witnessing a day-by-day accumulation of aerosols in the lower $2000 \mathrm{~m}$ of the Troposphere (Fig. S2). The accumulation ceased in the night of 5 July, when a squall line crossed the Po Valley causing an efficient clean-up of the atmosphere. During the following days of perturbed weather and westerly air masses, the PBL meteorology traced by $\mathrm{NO}_{\mathrm{x}}$-ozone concentrations and by the lidar aerosol extinction showed a less pronounced diurnal cycle.

\subsection{Size-segregated aerosol composition from multistage impactors}

Figure 1 reports the size distributions of the main aerosol chemical components determined in the impactor samples. Averaged compositions are provided for the campaign periods identified on the basis of air mass classification (see Sect. 3.1). Days from 28 June to 4 July were characterised by relatively high concentrations, especially at night, due to large accumulation mode aerosols $(\sim 0.4-1 \mu \mathrm{m})$ rich in ammonium, nitrate, sulfate and water-soluble organic compounds. A constant night-time composition throughout the first week of the experiment indicates a persistent source of secondary inorganic species and of carbonaceous particles from ground-level sources in the Po Valley, because these samples were collected in conditions of atmospheric stratification. The daytime concentrations were significantly lower than at night on the first days (28-29 June), while in the following days the daytime concentrations converged towards night-time levels. The progressive, day-by-day build-up of aerosol daytime concentrations was concomitant to the accumulation of aerosols in residual layers (Fig. S2). The convergence of the daytime chemical composition towards the nocturnal (nitrate-rich) composition can be explained by the recirculation of aerosol formed from ground-level sources in the Po Valley into the residual layers. In other words, particles from Po Valley sources accumulated every night in a shallow stable surface layer and were ventilated every morning during the mixing layer formation, and, after several days in stagnant conditions, this process caused the entire PBL to fill with such particles, so that the mixing layer formation did not cause significant dilution anymore.

On 6 July, after a strong precipitation event during the previous night, concentrations were small for all species, with the exception of sulfate and water-soluble organics. The period of westerly air masses ( 7 to 9 July) showed greater concentrations of coarse particles with respect to previous days, with much sea salt and nitrate (Fig. 2). The size distribution of nitrate is skewed in fine size range. The presence of coarse mode sea salt in west-type air masses is incompatible with long-range transport in the free troposphere and can be explained by the influence of a surface circulation from the Gulf of Lyon and the Ligurian Sea triggered by the main westerly synoptic flow. This also means that the aerosol collected during the west-type regime was not necessarily more aged than those sampled in PoV air masses. During the last two days (11-12 July), following the end of the westerly circulation and the re-establishment of continental air masses, sea salt concentrations decreased and the size-segregated chemical composition was characterised again by high concentrations of fine secondary species and organic compounds. However, when compared to the composition characteristics of the first week, the daytime concentration of ammonium nitrate on 11-12 July was very small, and at night the nitrate size distribution did not peak in the $0.42-1.2 \mu \mathrm{m}$ size range but was rather equally distributed between the small $(0.14-0.42 \mu \mathrm{m})$ and large $(0.42-1.2 \mu \mathrm{m})$ accumulation mode size intervals. In general, the shape of the size distribution on 11-12 July, with a less distinct peak in the large accumulation mode size range with respect to the composition observed during the first week of the campaign, is characteristic of a less processed aerosol.

\subsection{Submicron aerosol chemical composition from HR-ToF-AMS and SP-AMS}

The modifications of the HR-ToF-AMS chemical composition following the changes in air mass type can be followed in Fig. 3 (upper panel), showing some general trends already highlighted by the impactor measurements: submicron nitrate is strongly reduced during the days of westerly air masses; the whole organic matter exhibits higher concentrations during days of continental ( $\mathrm{PoV})$ air masses, with increasing concentrations during the first week of the campaign (from 28 June to 5 July). Interestingly, the AMS nitrate concentrations are very small in daytime, in contrast with the results for submicron particles from Berner impactors and from ATOFMS (see Sect. 3.5), which both show several days with non-negligible concentrations in daytime (Fig. S4). The reason for such discrepancy cannot be fully clarified but it may be due to the different cut-offs used for the above instruments.

The high time resolution allows examination of the daily cycles of the main chemical components (Fig. 4b): nitrate concentrations peak at 04:00-05:00 LT when RH is highest; sulfate trend is rather flat but with a relative maximum during the daytime, between 10:00 and 17:00 LT; organic matter diurnal trend shows two maxima, the main one during nighttime (between 21:00 and 06:00 LT), and a second one around midday concomitant with that of sulfate. These maxima can be interpreted as due to condensation of semivolatile components into the aerosol at night (Dall'Osto et al., 2009) and photochemical formation of SOA.

The SP-AMS measurements covered only the second part of the study (6-12 July) while the HR-ToF-AMS was online $80 \%$ of the time during the experiment. Absolute concentrations for the chemical compounds determined by the SP-AMS are not discussed in this study as the instrument was uncalibrated; therefore, only relative concentrations are 


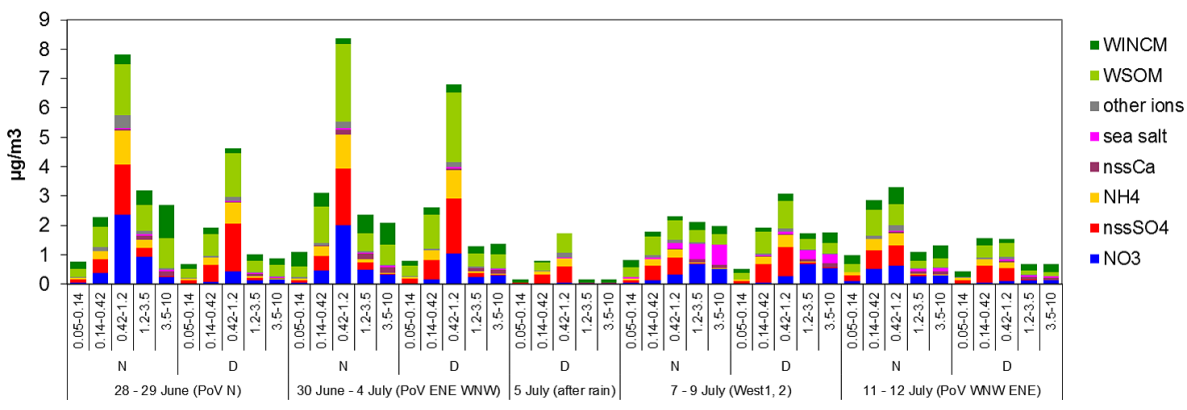

Figure 1. Size-segregated aerosol compositions from 5-stage Berner impactors. Averages for five periods of the campaign and for night $(N)$ and day $(D)$ samples are shown. For each period, prevalent back-trajectory types are reported. The impactor size intervals (as ambient aerodynamic diameters) corresponding to the stages are $0.05-0.14,0.14-0.42,0.42-1.2,1.2-3.5$ and $3.5-10 \mu \mathrm{m}$. WSOM (water-soluble organic matter $)=$ WSOC $1.9 ;$ WINCM $($ water-insoluble carbonaceous matter $)=($ TC-WSOC $) \cdot 1.2$.
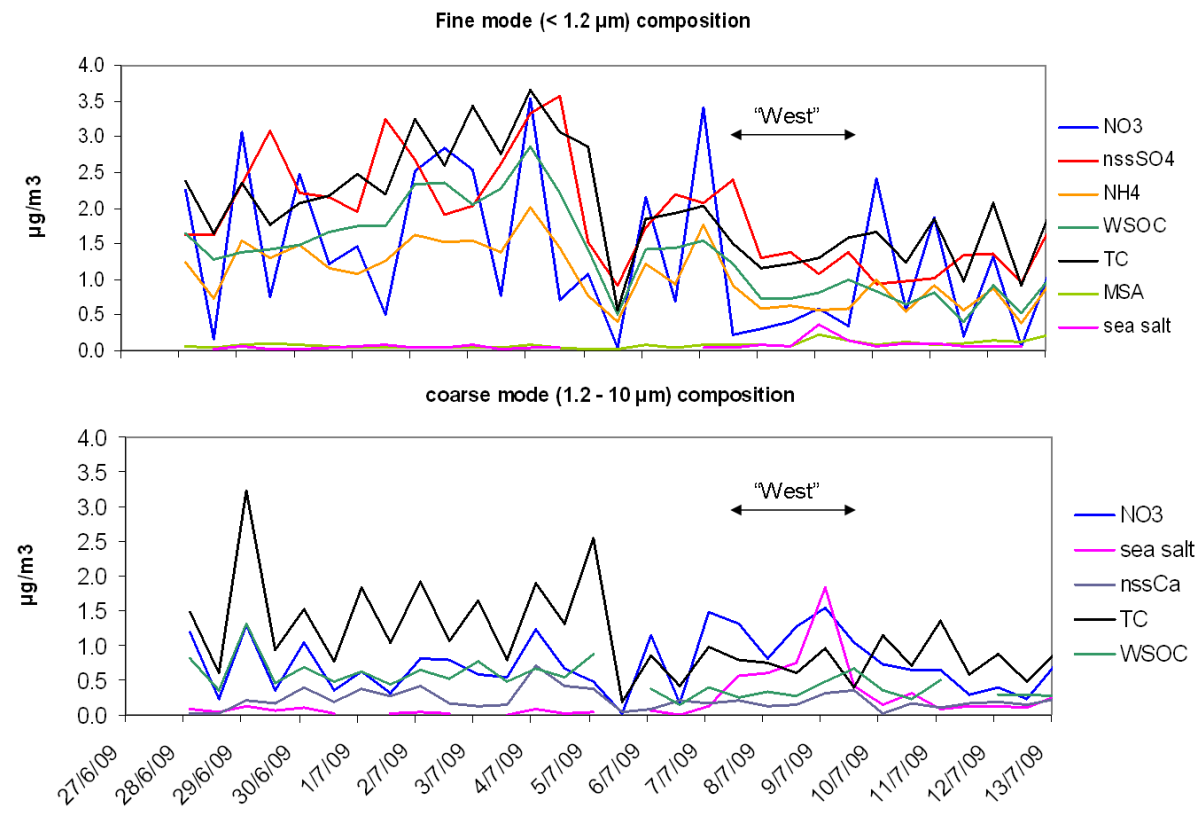

Figure 2. Time trends of main fine and coarse aerosol chemical components. The $x$ axis reports the mean time in each sampling interval. Days characterised by westerly air masses are indicated in the figure.

discussed. The shape of the BC time trend from SP-AMS overlaps well with the PSAP measurements, suggesting that the MAC value was relatively stable during the campaign (Fig. S5a). The pie charts in Fig. 5 summarise the $\mathrm{PM}_{1}$ chemical composition from HR-ToF-AMS for the whole campaign and for the measurement period covered by the SPAMS. The average chemical composition from SP-AMS is also shown for the same period. The picture is sensitive to the variability in the relative ionisation efficiency (RIE) in the SP-AMS. RIE values can be assumed based on Onasch et al. (2012). While this carries with it an uncertainty due to the lack of an in situ calibration, experience has taught us that the RIE values will not vary by too large an amount, so the pie chart in Fig. 5 is still meaningful. HR-ToF-AMS is insensitive to black carbon, so that $\mathrm{BC}$ mass concentrations were derived from the PSAP using a MAC of $10 \mathrm{~m}^{2} \mathrm{~g}^{-1}$. The mass balance of $\mathrm{PM}_{1}$ from HR-ToF-AMS shows a composition typical for polluted rural sites (Jimenez et al., 2009) with about a half of the mass accounted for by carbonaceous material and a nitrate/sulfate ratio exceeding 0.6. Similar proportions are found in the second part of the study (6-12 July), except for a smaller amount of BC. In the same period, the SP-AMS composition provides a very different picture, with a much greater contribution of $\mathrm{BC}$ but also of organic matter to the total analysed mass. The nitrate-to-sulfate ratio is also higher $(\sim 0.9)$ from the SP-AMS than from the HR-ToF-AMS. As mentioned above, the SP-AMS concentrations were uncalibrated; however, we can assume that the measured refractory $\mathrm{BC}$ is equivalent to the $\mathrm{BC}$ estimated from the PSAP $\left(0.40 \mu \mathrm{g} \mathrm{m}^{-3}\right.$ on average) assuming a value 


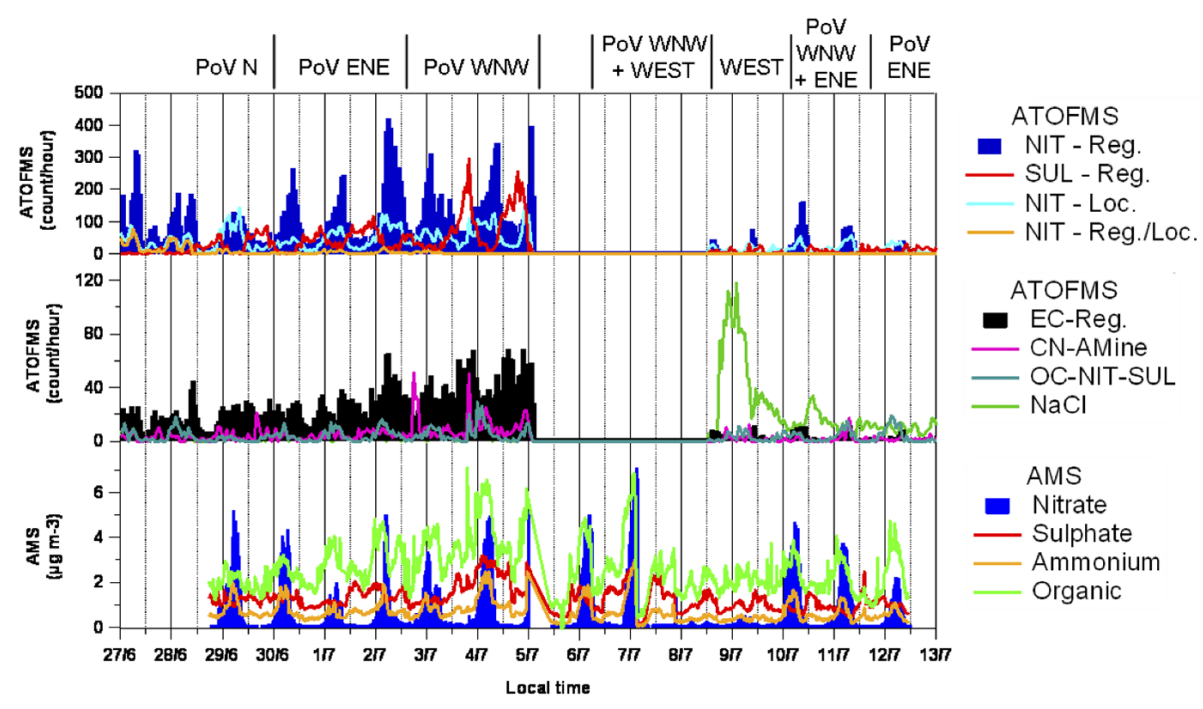

Figure 3. AMS general trends, and ATOFMS main clusters.

a)
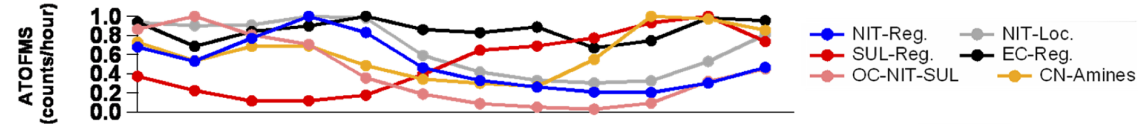

b)
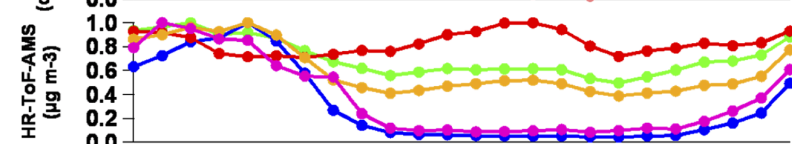

c)
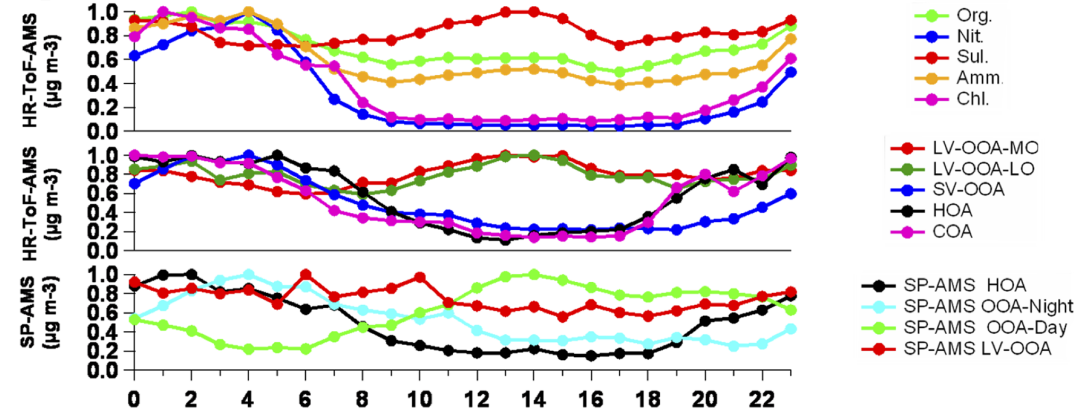

Local time

Figure 4. Diurnal trends of the main aerosol components from (a) ATOFMS, (b) HR-ToF-AMS (OM (organic matter), ionic components), (c) HR-ToF-AMS (PMF factors), (d) SP-AMS PMF factors.

of MAC of $10 \mathrm{~m}^{2} \mathrm{~g}^{-1}$ then the total SP-AMS mass would amount up to one-third of the mass concentrations from the HR-ToF-AMS, with a higher fraction for organic matter $(38 \%)$ than for nitrate $(19 \%)$ and sulfate $(15 \%)$. Such ratios are sensitive to the assumptions on the MAC value. However, only by assuming unrealistically low values of MAC $\left(<3 \mathrm{~m}^{2} \mathrm{~g}^{-1}\right)$, the PSAP BC concentrations would show ratios with the HR-ToF-AMS non-refractory components that fit the BC-to-sulfate or BC-to-nitrate ratios found in the SPAMS. Therefore, the depletion of non-refractory components with respect to $\mathrm{BC}$ observed in the SP-AMS is real, and points to contributions of sulfate, nitrate and organic matter externally mixed with $\mathrm{BC}$. When comparing the time trends of the concentrations of the main aerosol components measured by both HR-ToF-AMS and SP-AMS, there were slight differences in the time trends of the specific components between the two instruments (Fig. 6). It can be observed, for example, that the concentration ratio between the HR-ToF and the SP for nitrate on 6 and 7 July was twice that on 10 to 12 July. These observations provide further confirmation that the chemical composition and not a systematic instrumental source of error is responsible for the nitrate differences.

\subsection{Precursors of secondary inorganic and organic species from CIMS}

Daily cumulative production rates of sulfuric and nitric acid were calculated from $10 \mathrm{~min}$ integrated production rates starting from the measured $\mathrm{SO}_{2}$ (Fig. S3), $\mathrm{NO}_{2}$ and $\mathrm{OH}$ concentrations (Fig. 7, middle panel). Such production rates were compared to the ambient AMS concentrations for nitrate and sulfate. The cumulative formation of nitric acid on a daily basis varied between 10 and $30 \mu \mathrm{g} \mathrm{m}^{-3}$, showing that local $\mathrm{HNO}_{3}$ production is much higher than what is 

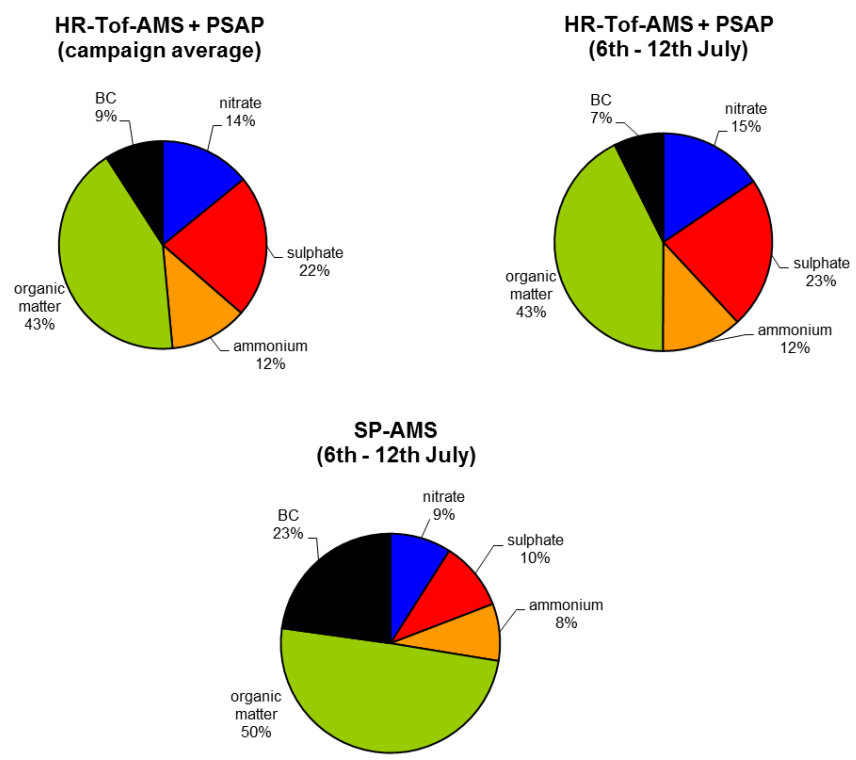

Figure 5. Average $\mathrm{PM}_{1}$ chemical composition from HR-ToF-AMS and SP-AMS.

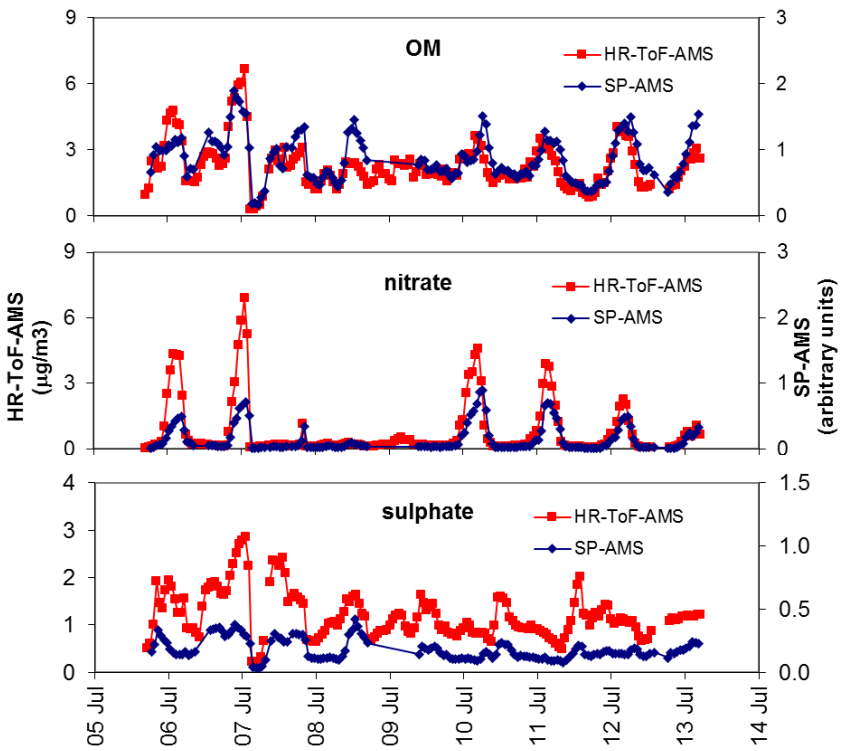

Figure 6. Temporal trends of organic matter, nitrate and sulfate obtained by SP-AMS and HR-ToF-AMS. The vertical scale for SPAMS is three times amplified with respect to the scale for the HRToF.

incorporated into the aerosol typically in the second half of the night, when temperatures are lowest and relative humidity exceeds $80 \%$ (see the HR-ToF-AMS data). Thus, $\mathrm{NO}_{2}$ oxidation by $\mathrm{OH}$ can account for the observed local production of aerosol nitrate. With respect to sulfuric acid, the gas phase is depleted rapidly and all $\mathrm{H}_{2} \mathrm{SO}_{4}$ condenses and is detected as sulfate aerosol (deposition to the ground should be a smaller loss path). The daily cumulative $\mathrm{H}_{2} \mathrm{SO}_{4}$ produc-
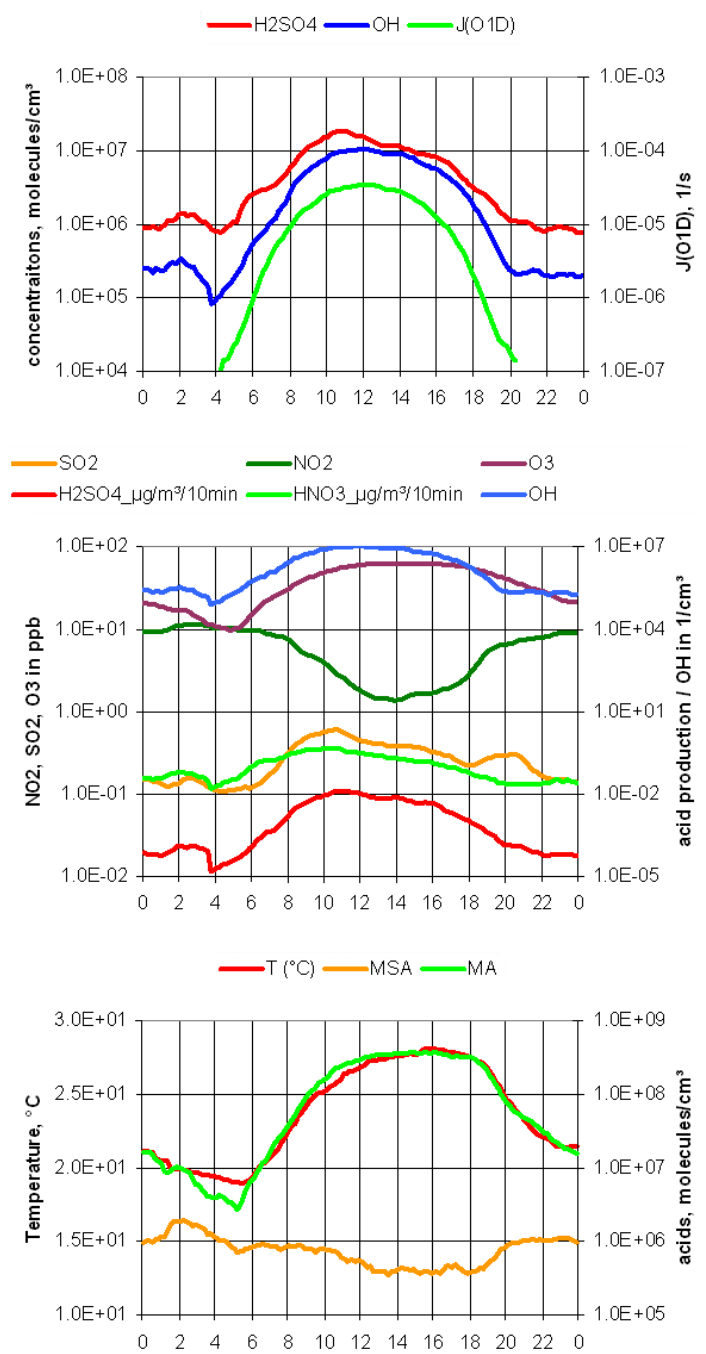

Figure 7. Mean daily cycles of gas-phase compounds. Upper panel: $\mathrm{OH}$ and $\mathrm{H}_{2} \mathrm{SO}_{4}$ concentrations and $J\left(\mathrm{O}^{1} \mathrm{D}\right)$; Middle panel: mixing ratios of $\mathrm{SO}_{2}, \mathrm{NO}_{2}$ and $\mathrm{O}_{3}$ (left), $\mathrm{OH}$ concentration (molecules $\mathrm{cm}^{-3}$ ) and the formation rates of $\mathrm{H}_{2} \mathrm{SO}_{4}$ and $\mathrm{HNO}_{3}\left(\mu \mathrm{g} \mathrm{m}^{-3} / 10 \mathrm{~min}\right.$ ) (right axis); Lower panel: temperature and acid concentrations (MSA: methanesulfonic acid, MA: malonic acid).

tion rates of $0.1-0.6 \mu \mathrm{g} \mathrm{m}^{-3}$ are roughly in line with diurnal variations in the aerosol sulfate. However, sulfate is also transported to the site, and is likely also exported from the site. Thus, even if aerosol sulfate and $\mathrm{HNO}_{3}+$ aerosol nitrate are advected to SPC through the PBL dynamics highlighted above, local production also takes place.

Gas-phase organic compounds were also measured by CIMS, and namely malonic acid (MA) and methanesulfonic acid (MSA) were detected during the campaign. While the diurnal cycle of MSA was rather flat, it is interesting to note that malonic acid has a very consistent diurnal variation closely related to temperature (Fig. 7, lower panel). This result indicates that organic compounds with the volatility of 
MA (in the range of $10^{-3} \mathrm{~Pa}$ or $10^{-5}$ Torr; Pope et al., 2010) like $\mathrm{C} 20$ alkanes or $\mathrm{C} 14$ alkanoic acids experienced significant variations in the gas-to-particle partitioning between day and night under the ambient conditions encountered in the present study and potentially contributed to the nocturnal increase of organic aerosol concentrations found by the HR-ToF-AMS (Fig. 4b).

\subsection{Aerosol single-particle analysis by ATOFMS}

The TSI ATOFMS provided good measurement coverage during the experiment (Fig. 3). About 65000 single particle mass spectra were collected. ART-2a cluster analysis was performed on the total ATOFMS data set. In other words, the analysis was carried out on single particles containing both positive and negative mass spectra and also on the ones containing only one of the two mass spectra (Song et al., 1999; Dall'Osto and Harrison, 2006). There were twelve particle types in total. Eight main particle types were found. Four additional particle types were found but were only present as spike events on selected days. Table 1 summarises the frequency of the eight main particle types, and the relative mass spectra can be seen in Fig. 8. These eight particle types are described as follows, using a nomenclature based on the spectral features and on the possible source patterns inferred from the analysis of the size distributions and of the concentration time trends presented later in this section:

- EC-Reg: aged regional elemental carbon (12\%). The mass spectrum shows strong peaks due to elemental carbon (EC, Cn, $m / z$ 12, 24, 36, 48, 60). This particle type has an aerodynamic diameter $\left(D_{\mathrm{a}}\right)$ of about $700 \mathrm{~nm}$ (accumulation mode, by particle number size distribution) and is the typical particle seen for aged, regional aerosol. Such particles must be considered as enriched in EC instead of being pure EC, even if the EC-Reg particle type did not present a negative mass spectrum; thus, it is not possible to gain any information about the nature of the chemical species internally mixed with EC for this particle type. It is important to note that the ATOFMS is particularly sensitive to EC due to the light used for the LDI process in the ATOFMS. This EC-Reg. particle type was only described by elemental carbon peaks contained in the positive mass spectra. Giorio et al. (2012) showed that whilst negative EC peaks are related to anthropogenic primary emissions, positive EC peaks are more present in aged particles internally mixed with secondary species. It has been shown that the condensation of secondary material on soot particles (Moffet and Prather, 2009) and the consequent change in aerosol hygroscopicity (Spencer et al., 2007) can suppress the formation of negative ions in real-time laser desorption/ionisation mass spectrometry, causing many aged EC-containing particles to lack negative mass spectra (Neubauer et al., 1998).
- NIT-Reg: nitrate of regional origin (48\%). Strong peaks due to nitrate $\left(m / z-46\left[\mathrm{NO}_{2}\right], m / z-62\left[\mathrm{NO}_{3}\right]\right)$ are observed along with those of EC in large particles ( $D_{\mathrm{a}} \sim 700 \mathrm{~nm}$, similar to the EC-Reg. cluster). These aerosols originate from the night-time condensation of nitric acid on BC-containing primary particles (e.g. Shiraiwa et al., 2007). This particle cluster corresponds to the regional nitrate already detected at other European locations (Dall'Osto et al., 2009).

- NIT-Loc.: nitrate of local origin (22\%). This particle type is characteristic of nitrate aerosol in small particles ( $D_{\mathrm{a}}$ at about $300-500 \mathrm{~nm}$ ) and unmixed with EC. The peak at $m / z 39$ can be due to potassium, although previous studies (Dall'Osto et al., 2009) suggested that an organic contribution may be present depending on the $\mathrm{m} / z$ 39/41 ratio. The diurnal cycle of NIT-Loc is less RH-dependent than that of NIT-Reg. This particle type has already been observed in the study by Dall'Osto et al. (2009).

- SUL-Reg.: sulfate of regional origin (4\%). This particle type - rich in elemental carbon and sulfate - had a smaller $D_{\text {a }}$ than NIT-Reg, at about $500 \mathrm{~nm}$, and was seen mainly during daytime. The NIT-Reg and SULReg. diurnal trends are clearly anticorrelated (Fig. 4a), with SUL-Reg concentrations peaking in the afternoon hours. Such behaviour, already observed by Dall'Osto et al. (2009) in London, was attributed to the effect of the diel cycle of nitric acid + ammonia condensation/evaporation on the same particle type: during night-time this regional particle type is seen with nitrate, which evaporates during daytime leaving a smaller aerosol core composed of EC and sulfate.

- NIT-Loc/Reg.: mixed nitrate of local and regional ori$\operatorname{gin}(3 \%)$. This particle type is characterised by small particles $\left(D_{\mathrm{a}} \sim 450 \mathrm{~nm}\right)$ and by a spectrum which is a hybrid between those of NIT-Local and NIT-Reg: the major peaks are at $m / z 36$ (EC), $m / z 39$ (K, OC), nitrate $(m / z-46, m / z-62)$.

- NaCl: sodium chloride (6\%). This particle type is characterised by mass fragments from $\mathrm{Na}(m / z 23), \mathrm{Na}_{2} \mathrm{Cl}$ $(m / z 81)$ and a lesser peak from $\mathrm{Cl}(m / z-35)$. The mass spectrum also exhibits nitrate peaks $(\mathrm{m} / z-46$ and $m / z-62$ ) reflecting the reaction between $\mathrm{NaCl}$ and $\mathrm{HNO}_{3}$ and the displacement of chloride by nitrate (Gard et al., 1998). NaCl particles were seen mainly during 9-11 July under west-type marine air masses, with a very good correlation with the time trends of sea salt concentrations determined on the Berner impactors $\left(r^{2}=0.95\right)$.

- K-CN-amine: potassium + organic nitrogen with amines (3\%). This particle type is smaller than NITReg with a $D_{\mathrm{a}}$ of about $550 \mathrm{~nm}$. A strong peak at $m / z 39$ 
Table 1. ATOFMS clusters.

\begin{tabular}{lrr}
\hline cluster & $N$ particle & $\%$ \\
\hline NIT-Reg & 24409 & 48 \\
NIT-Local & 10979 & 22 \\
EC-Reg & 5902 & 12 \\
SUL-Reg & 1910 & 4 \\
K-CN-Amine & 1368 & 3 \\
NIT-Local/Reg & 1419 & 3 \\
OC-NIT-SUL & 1208 & 2 \\
NaCl & 3114 & 6 \\
spikes & 548 & 1 \\
TOT & 50857 & 100 \\
\hline
\end{tabular}

is seen in the positive mass spectra, due to potassium (K) or unidentified OC components. This particle type was found also internally mixed with organic nitrogen $\left(\mathrm{m} / z-26\right.$ and $m / z-42$, due to $[\mathrm{CN}]^{-}$and $[\mathrm{CNO}]^{-}$, respectively). The strong peak at $m / z 59\left(\left[\mathrm{~N}\left(\mathrm{CH}_{3}\right)_{3}\right]^{+}\right)$ is recognised as the dominant peak for trimethylamine (TMA) since it could not be produced from any other common amine species in previous laboratory studies (Angelino et al., 2001). This particle type was found internally mixed with nitrate and sulfate. Other amines can be seen at specific peaks (i.e. $m / z 86$ ) but in this study such mass fragments were seen only sporadically with no clear time trends.

- OC-NIT-SUL: organic carbon+nitrate+sulfate (2\%). This cluster presents a unique positive mass spectrum (Fig. 8), with strong peaks at $m / z 27\left[\mathrm{C}_{2} \mathrm{H}_{3}\right]^{+}$and $m / z 43\left[\left(\mathrm{CH}_{3}\right) \mathrm{CO}\right]^{+}$usually associated with oxidised secondary organic aerosol, and $m / z 51\left[\mathrm{C}_{4} \mathrm{H}_{3}\right]^{+}, 63$ $\left[\mathrm{C}_{5} \mathrm{H}_{3}\right]^{+}, 77\left[\mathrm{C}_{6} \mathrm{H}_{5}\right]^{+}$and $91\left[\mathrm{C}_{7} \mathrm{H}_{7}\right]^{+}$which are indicative of a strong aromatic signature (McLafferty, 1993). The strong signals at $m / z, 29\left[\mathrm{C}_{2} \mathrm{H}_{5}\right]^{+}$and $m / z 41\left[\mathrm{C}_{3} \mathrm{H}_{5}\right]^{+}$confirm the strong hydrocarbon-like signature. The particle size distribution of this cluster is bimodal with peaks at about 400 and $600 \mathrm{~nm}$. When plotting the temporal trend of the two different size modes, there are no observed differences.

The aerosol populations attributed to regional sources (EC-Reg, NIT-Reg and SUL-Reg) were, per definition, more abundant during the first part of the study characterised by stagnant conditions with a greater extent of pollutant recirculation (Fig. 3, Table S1). EC-Reg particle concentrations slowly accumulated over time (until the 5 July storm), suggesting an advection to the site in recirculated PBL air. Aged aerosols with large $\mathrm{BC}$ cores were observed also in the study of Laborde et al. (2013) in Paris. NIT-Reg concentrations are also highest during the first part of this study in connection with PoV air masses, but, contrary to EC-Reg, their diurnal trend shows concentration peaks during the night/morning hours when relative humidity is highest (Fig. $4 \mathrm{a}$ ). The BC loadings from PSAP (Fig. S5b) show a time trend which is a broad overlap of the sum of the concentrations of the ECcontaining ATOFMS particle types: a component with nocturnal maxima (that the ATOFMS attributes to NIT-Reg) is superimposed upon a component which persists in daytime and accumulates in recirculated PBL air, including ATOFMS particles with EC internally mixed with sulfate (SUL-Reg), nitrate (NIT-Reg) or without any coating component visible to the ATOFMS (EC-Reg).

The second part of the study was characterised by much lower concentrations of EC-Reg, NIT-Reg and SUL-Reg. Noticeably, during the first part of the study, the ratio of regional nitrate to local nitrate (NIT-Loc) is about three, whereas during the second part of the study the ratio is about one. It is important to note that these results are in line with those of the Berner impactors, showing that during the last days of the campaign, submicron nitrate was associated with smaller particles than during the first week of the study (Fig. S4). Clearly, the last days of the experiment (11-12 July) were less affected by regional sources of nitrate aerosols with respect to the first, more polluted week of the campaign.

EC-Reg, NIT-Reg, NIT-Loc, SUL-Reg and $\mathrm{NaCl}$ were also found in a very different environment, during the REPARTEE campaign in London and the SAPUSS campaign in Barcelona (Harrison et al., 2012; Dall'Osto et al., 2013), and provide therefore evidence that such ATOFMS particle populations can be common over vast European regions. The other four additional particle types found in this study account for smaller contributions to the particle loading at SPC (Table 1). The $\mathrm{K}-\mathrm{CN}$-amine particle type shows a peak at about 18:00-21:00 LT, and mainly during 2-4 July with specific Po Valley trajectories (PoV WNW). The NIT-Loc/Reg particle type exhibits a time trend with a maximum at the very beginning of the experiment (27-29 June) under PoV $N$ air mass trajectories. The diurnal trend for organic particles mixed with secondary inorganic species (OC-NIT-SUL) exhibits a nocturnal maximum, but without an early morning peak, i.e. without any clear enrichment effect from enhanced relative humidity conditions. The time trends of $\mathrm{K}-\mathrm{CN}$-amine and OC-NIT-SUL show small concentrations in daytime and no accumulation during the period of stagnant conditions, pointing to an origin from local sources and a relatively fast dispersion or transformation in the atmosphere.

\subsection{Organic composition from PMF-AMS}

In the sections above we have discussed concentrations and variability of the main inorganic aerosol components, organic matter and black carbon as well as their mixing state. This section deals with organic compound composition and organic source apportionment. 

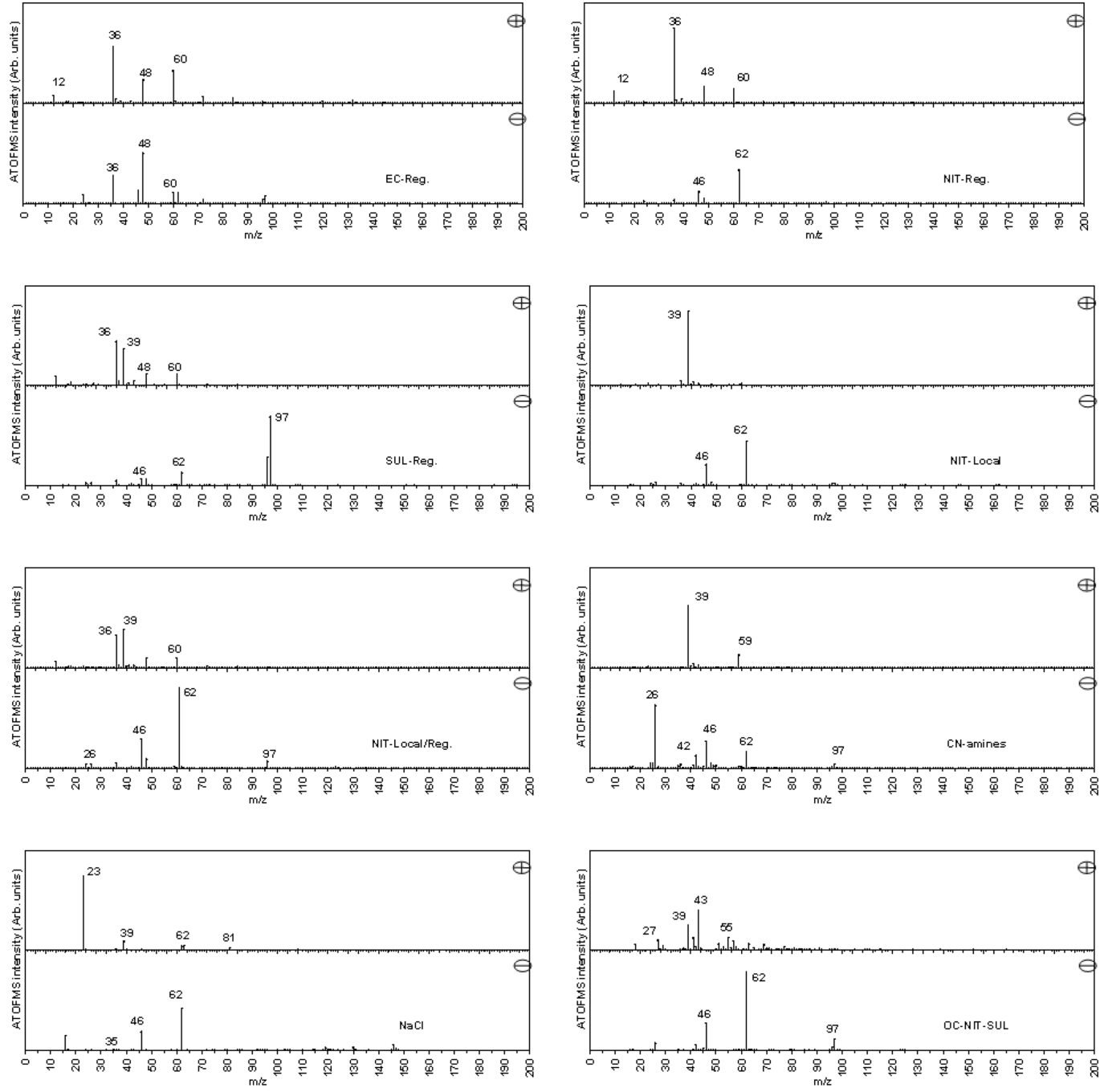

Figure 8. Mass spectra of the ATOFMS clusters.

\subsubsection{HR-ToF-AMS PMF}

Insight into the nature and origin of submicron organic aerosol (OA) was provided by positive matrix factorisation (PMF) of AMS data sets (Ulbrich et al., 2009). PMF was run on both low- and high-resolution HR-ToF-AMS organic matrices. We discuss here the five-factor solution for the highresolution data set (Figs. 9 and S6) The reasons for selecting such number of factors are discussed in the Supplement (Table S2, Figs. S7 and S8).

- HOA: hydrocarbon-like OA, comprising $14 \%$ of OA. This factor contains the typical hydrocarbon-like primary organic aerosol dominated by organic fragments for saturated hydrocarbons $\left[\mathrm{C}_{\mathrm{n}} \mathrm{H}_{2 \mathrm{n}+1}\right]^{+}(m / z 29,43$, $57,71)$ and unsaturated hydrocarbons $\left[\mathrm{C}_{\mathrm{n}} \mathrm{H}_{2 \mathrm{n}-1}\right]^{+}$ $(m / z 27,41,55,69,83)$. This factor is characterised by a very low $\mathrm{O} / \mathrm{C}$ ratio $(0.05)$ and is very similar to previously reported reference spectra of primary organic

aerosol emitted from gasoline and diesel combustion sources (Canagaratna et al., 2004; Aiken et al., 2009).

- COA: cooking organic aerosol, comprising $8 \%$ of OA, this spectrum is similar to the cooking aerosol seen in previous published studies (Allan et al., 2010; Mohr et al., 2012). An additional unique feature among all factors is having $m / z$ of $41\left(\left[\mathrm{C}_{3} \mathrm{H}_{5}\right]^{+}\right)$as a clear hydrocarbon peak. The second strongest $\left[\mathrm{C}_{\mathrm{x}} \mathrm{H}_{\mathrm{y}}\right]^{+}$peak can be seen at $m / z 55\left(\left[\mathrm{C}_{4} \mathrm{H}_{7}\right]^{+}\right)$, as well as $m / z 67\left(\left[\mathrm{C}_{5} \mathrm{H}_{7}\right]^{+}\right)$. However, oxidised organic carbon peaks can also be seen and the $\mathrm{O} / \mathrm{C}$ ratio is higher than for the HOA type (0.24). The $m / z 43$ is mainly composed of its oxidised fraction $\left(\left[\mathrm{C}_{2} \mathrm{H}_{3} \mathrm{O}\right]^{+}\right)$as well as the presence of a strong signal at $m / z 44\left(\left[\mathrm{CO}_{2}\right]^{+}\right)$.

- SV-OOA: semivolatile oxygenated organic aerosol, comprising $17 \%$ of OA. We use the terms LV-OOA (LV - low volatility) and SV-OOA (SV - semivolatile) as 


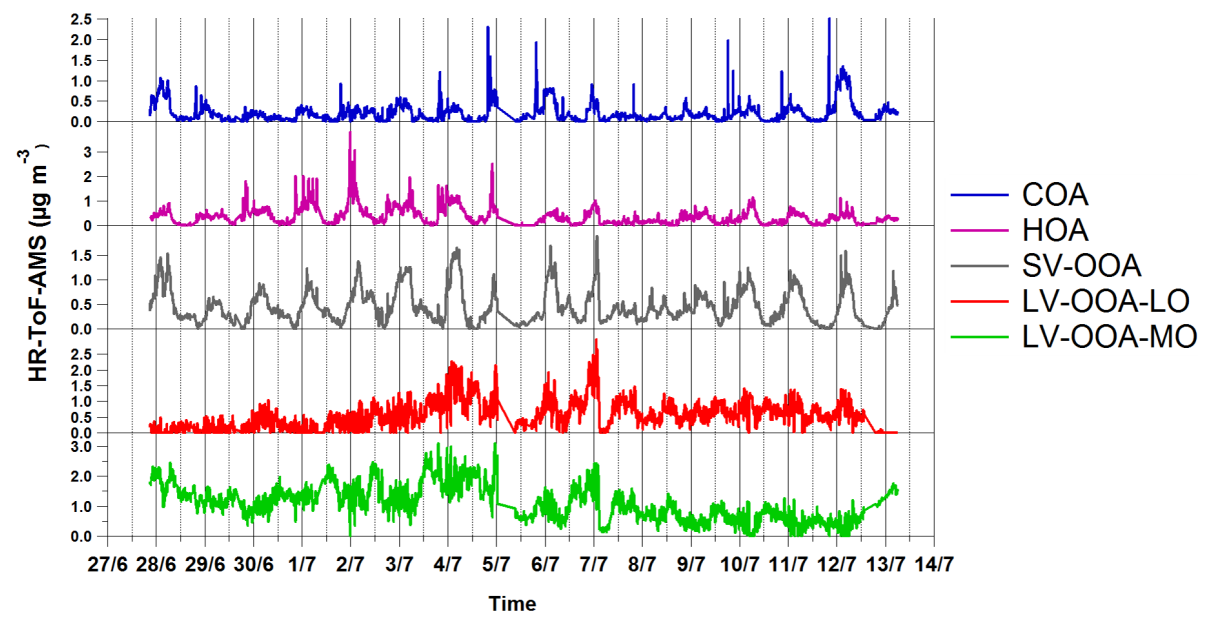

Figure 9. Temporal trend of the five HR-ToF-AMS organic factors. Concentrations in $\mu \mathrm{g} \mathrm{m}^{-3}$.

introduced by Jimenez et al. (2009) although we did not explicitly measure the volatility of the compounds within this study. LV-OOA and SV-OOA factors serve as a basis set for describing the range of physicochemical properties occurring in the dynamic evolution of OOA (Jimenez et al., 2009). The mass spectrum of this component is clearly characterised by prominent $\mathrm{C}_{\mathrm{x}} \mathrm{H}_{\mathrm{y}} \mathrm{O}_{\mathrm{z}}$ fragments, especially $\mathrm{CO}_{2}{ }^{+}(m / z 44)$, indicating presence of a substantial amount of oxidised organic compounds, resulting in a $\mathrm{O} / \mathrm{C}$ ratio $(0.37)$ which is substantially higher than for HOA and COA.

- LV-OOA-LO: low-volatility-OOA-less oxidised, comprising $22 \%$ of OA. This factor has a very similar spectrum to a typical LV-OOA type (Ulbrich et al., 2009; $\left.r^{2}=0.8\right)$ with a high $\mathrm{O} / \mathrm{C}$ ratio $(0.70)$. However, the spectral profile contains minor peaks of non-oxygenated structures (e.g. $\left[\mathrm{C}_{4} \mathrm{H}_{7}\right]^{+},\left[\mathrm{C}_{4} \mathrm{H}_{9}\right]^{+},\left[\mathrm{C}_{5} \mathrm{H}_{4}\right]^{+},\left[\mathrm{C}_{5} \mathrm{H}_{9}\right]^{+}$, $\left.\left[\mathrm{C}_{5} \mathrm{H}_{11}\right]^{+}\right)$in greater amounts with respect to the other LV-OOA type resolved by PMF in this study (see below). We therefore interpret this one as less aged OOA.

- LV-OOA-MO: low-volatility-OOA-more oxidised, comprising $42 \%$ of OA. This factor displays a strong $\mathrm{m} / \mathrm{z} 28$ and 44 , as is typical of highly aged OOA as measured by AMS $(\mathrm{O} / \mathrm{C}$ ratio $=0.78)$. The mass spectrum of LV-OOA-MO illustrates a dominant peak at $\mathrm{m} / \mathrm{z} 44$ $\left(\left[\mathrm{CO}_{2}\right]^{+}\right)$, similar to the more oxidised LV-OOA component determined at other urban sites (Lanz et al., 2007; Ulbrich et al., 2009; $r^{2}=0.9$ ).

The emerging picture is in line with previous PMFAMS analyses of the sources of OA in continental polluted sites: (a) primary OA (HOA and COA) accumulates overnight because of the reduced atmospheric mixing and dispersion; (b) HOA concentrations follow those of $\mathrm{NO}_{\mathrm{x}}$ $\left(r^{2}=0.51\right)$ pointing to contributions from traffic sources; (c)
SV-OOA accumulates at night-time, with concentrations depending not only on source strength and transport but also on temperature, which explains the correlation with inorganic semivolatile compounds $\left(r^{2}=0.60\right.$ with ammonium nitrate). Finally, (d) the most oxidised factors (the two LVOOA types) provide the greatest contribution to OM concentrations during daytime. LV-OOA-MO concentrations maximise during the first part of the study, whilst the contribution of the less oxidised LV-OOA-LO is relatively larger during the second part of the study. The differences between the possible sources of the two factors will be discussed further in Sect. 4.2. It is worth stressing that the occurrence of multiple types of OOA is not new in the literature of PMF-AMS studies, both in the Po Valley (Saarikoski et al., 2012; Paglione et al., 2014) and in other regions (Chen et al., 2014).

We examined the correlation of AMS LV-OOA $(\mathrm{MO}+\mathrm{LO})$ with odd oxygen $\left(\mathrm{O}_{\mathrm{x}}=\mathrm{O}_{3}+\mathrm{NO}_{2}\right)$ (Fig. S9) (Wood et al., 2010). The correlation is only weakly positive $\left(r^{2}=0.12\right)$. The main difference between $\mathrm{O}_{\mathrm{x}}$ and OOA is that concentrations of the former drop at night as an effect of dry deposition. In other words, ozone does not behave like aerosols, and this poses a limit to the application of this proxy. In daytime, the concentrations of LV-OOA are more closely related to that of ozone $\left(r^{2}=0.27\right)$, indicating that the maximum observed for the oxidised OOAs between 10:00 and 17:00 LT is associated with the production/entrainment of photochemical products.

In Table 2, we report the correlation coefficients (as $r^{2}$ ) between the concentration time trends of the HR-ToF-AMS factors and chemical components and those of the ATOFMS clusters. The concentration of AMS organic matter is correlated with many ATOFMS clusters, suggesting that, even if organic fragments were found for only a few specific clusters, organic matter could be internally mixed in several ATOFMS particle types and simply not seen with sufficient sensitivity by the ATOFMS. For instance, particle types containing 
Table 2. Correlation $\left(r^{2}\right)$ between AMS factors and chemical components, and ATOFMS clusters ( $3 \mathrm{~h}$ averages).

\begin{tabular}{|c|c|c|c|c|c|c|c|c|c|c|c|}
\hline & $\begin{array}{r}\text { AMS } \\
\text { LV-OOA-MO }\end{array}$ & $\begin{array}{r}\text { AMS } \\
\text { LV-OOA-LO }\end{array}$ & $\begin{array}{r}\text { AMS } \\
\text { SV-OOA }\end{array}$ & $\begin{array}{l}\text { AMS } \\
\text { HOA }\end{array}$ & $\begin{array}{l}\text { AMS } \\
\text { COA }\end{array}$ & $\begin{array}{c}\mathrm{AMS} \\
\mathrm{Cl}^{-}\end{array}$ & $\begin{array}{l}\mathrm{AMS} \\
\mathrm{NO}_{3}^{-}\end{array}$ & $\begin{array}{l}\mathrm{AMS} \\
\mathrm{SO}_{4}^{=}\end{array}$ & $\begin{array}{r}\text { AMS } \\
\text { Org }\end{array}$ & $\begin{array}{l}\mathrm{AMS} \\
\mathrm{NH}_{4}^{+}\end{array}$ & $\begin{array}{r}\text { PSAP } \\
\text { BC }\end{array}$ \\
\hline ATOFMS NIT-Rrg & 0.48 & & & 0.4 & & & 0.3 & & 0.35 & 0.35 & 0.4 \\
\hline ATOFMS NIT-Loc & & & & 0.45 & & & & & 0.37 & & 0.55 \\
\hline ATOFMS EC-Reg & 0.65 & & & & & & & 0.35 & & & 0.45 \\
\hline ATOFMS SUL-Reg & 0.45 & & & & & & & 0.4 & & & \\
\hline ATOFMS $\mathrm{K}-\mathrm{CN}$-Amine & & 0.3 & & 0.4 & & & & & 0.41 & & \\
\hline ATOFMS NIT-Loc/Reg & & & & & & & & & 0.4 & & \\
\hline ATOFMS OC-NIT-SUL & & & 0.7 & & 0.55 & & & & 0.4 & & \\
\hline
\end{tabular}

EC and showing a nocturnal accumulation (NIT-Reg) exhibit a correlation with AMS HOA, in agreement with a primary origin of hydrocarbon-like compounds from combustion sources in the Po Valley. The ATOFMS OC-NIT-SUL characterised by a unique $m / z 55$ signal correlates well with SV-OOA and the COA (whose spectrum also shows a $m / z 55$ fragment). Organic particles internally mixed with sulfatelike OC-NIT-SUL are compatible with the hypothesis of formation from condensation of semivolatile organics (SVOOA) onto pre-existing particles during the cold hours of the day. At the same time, the correlation of COA with OC-NIT-SUL, which represents a particle type not containing $\mathrm{EC}$, is compatible with the origin of cooking aerosols, which are emitted by thermal processes at temperatures that are too low to produce elemental carbon. Finally, the LVOOA-MO factor shows a positive correlation with ATOFMS particle types (NIT-Reg, EC-Reg, SUL-Reg) whose concentration time trends reflected an accumulation in the daytime PBL during the first week of the campaign, in agreement with our interpretation that the above three ATOFMS clusters were influenced by aged aerosol (regional) sources.

\subsubsection{SP-AMS PMF}

The PMF-SP-AMS is less standardised than PMF for the HR-TOF. We present here a four-factor solution obtained by processing the SP-AMS spectra recorded for OM $+\mathrm{BC}$ between 5 and 12 July (Figs. 4d and S10).

- HOA (16\% of OM) internally mixed with BC, typical signature of strong $m / z 43$ and $m / z 57$, strong BC signature. Nitrogen-containing fragments $(\mathrm{m} / \mathrm{z} 73$ and $m / z$ 58) are also visible and can be attributed to amines.

- OOA-Night (38 \% of OM), with strong peaks at $m / z 43$, $55,69,81$. The spectrum is reminiscent of that of the SV-OOA from HR-ToF-AMS, or a more oxidised traffic-related anthropogenic signature. It was observed mainly during night-time but showing sustained concentrations also in the early morning, consistent with semivolatile compound behaviour (Fig. 4d).

- OOA-Day (29\% of OM), with a very different spectrum with respect to OOA-Night and also an opposite diur- nal trend (Fig. 4d). The OOA-Day signature includes many more oxygenated fragments (red), reminiscent of the spectrum of a LV-OOA. Characteristic fragments are $m / z 39,41,55$ series, and a unique $m / z 31,45,85,99$, 111 attributable possible to ethers or saturated carbonyls (McLafferty et al., 1993), although this should be confirmed with laboratory studies currently not being carried out with SP-AMS.

- LV-OOA (17\% of OM), typical OOA, the most oxidised one. Its diurnal trend is flat (Fig. 4d), indicating a wellmixed, most aged OA.

The fact that PMF finds fewer factors in the SP-AMS data set than from the HR-ToF can be attributed to the fact that the SP-AMS record is shorter; therefore, it contains less variance. For this reason, beside the good correlation between the HOAs extracted from the two data sets $\left(r^{2}=0.45\right)$, attributing the SP-AMS factors to the HR-ToF-AMS factors is challenging. A lack of a HR-ToF-AMS factor being present in the SP-AMS factors could indicate that it is externally mixed with $\mathrm{BC}$, which would seem reasonable in the case of the cooking factors. Similarly, organic matter measured by SPAMS seems to have a lower LV-OOA contribution compared to the HR-ToF-AMS (In fact, the HR-ToF LV-OOA-MO correlates better with the SP-AMS OOA-Day $\left(r^{2}=0.65\right)$ than with the SP-AMS LV-OOA), which may indicate that a substantial fraction of the LV-OOA is externally mixed with $\mathrm{BC}$, although this may be due to technical differences between the vaporisation methods. It may be that the decarboxylation process responsible for the characteristic OOA mass spectrum during normal AMS vaporisation does not occur in the same manner in the SP-AMS. Furthermore, it is also possible that the vapours may be detected in the SP-AMS at different effective relative ionisation efficiencies (RIEs), which may affect the relative concentrations. More characterisation work will be required to explicitly evaluate this. Therefore, the comparison between the PMF factors from SP-AMS and HR-ToF-AMS presented in this study must be considered as preliminary. 


\subsection{Organic speciation from HR-ToFMS-TAG}

Organic marker information was provided by HR-TofMSTAG during the last days of the campaign (7-11 July). A 20-factor PMF solution was used to separate the complex chromatograms. Several of the factors resulted from factor splitting, and were recombined to compare with AMS and ATOFMS factors. Other factors are a result of thermal decomposition as evidenced by the early GC retention time. The main categories of HR-ToFMS-TAG PMF components include (Fig. S11, Table S3):

- alkanes: (two factors) one alkane factor is representative of an unresolved complex mixture (UCM), likely composed of many straight and branched alkanes;

- benzoic acid;

- monocarboxylic acids: (two factors) one monocarboxylic acid factor has a contribution from thermal decomposition at the start of chromatograms;

- organic nitrogen: (two factors) containing ions such as $m / z 30$ and 46 ;

- sulfate/organosulfate: containing ions such as $m / z 48$ and 64;

- chloride-containing: containing ions such as $m / z 36$;

- unknown decomposition products: (six factors) large contribution at beginning of chromatograms;

- unknowns: (four factors) unidentified factors that contribute little to the total ion signal;

- column bleed: GC column bleed typical of chromatography.

Figure 10 reports the time trends of the total concentrations of the three main classes of compounds along with the time series of external tracers (AMS and ATOFMS factors) with the aim of comparison. Clearly, alkanes correlated with the AMS HOA, as expected, but also with PSAP BC and the ATOFMS EC-containing particles supporting an origin of alkanes from primary combustion sources. Benzoic acid, a tracer for anthropogenic SOA (Williams et al., 2010), shows concentrations correlating with those of LV-OOA-MO. Finally, monocarboxylic acids show a positive correlation with AMS COA, which is consistent with the hypothesis of a prevalent source from food cooking (Williams et al., 2010). In summary, the TAG analysis supports the previous interpretations of the AMS and ATOFMS factors, at the same time providing unambiguous evidence of an anthropogenic contribution of aerosol organic matter in this study.
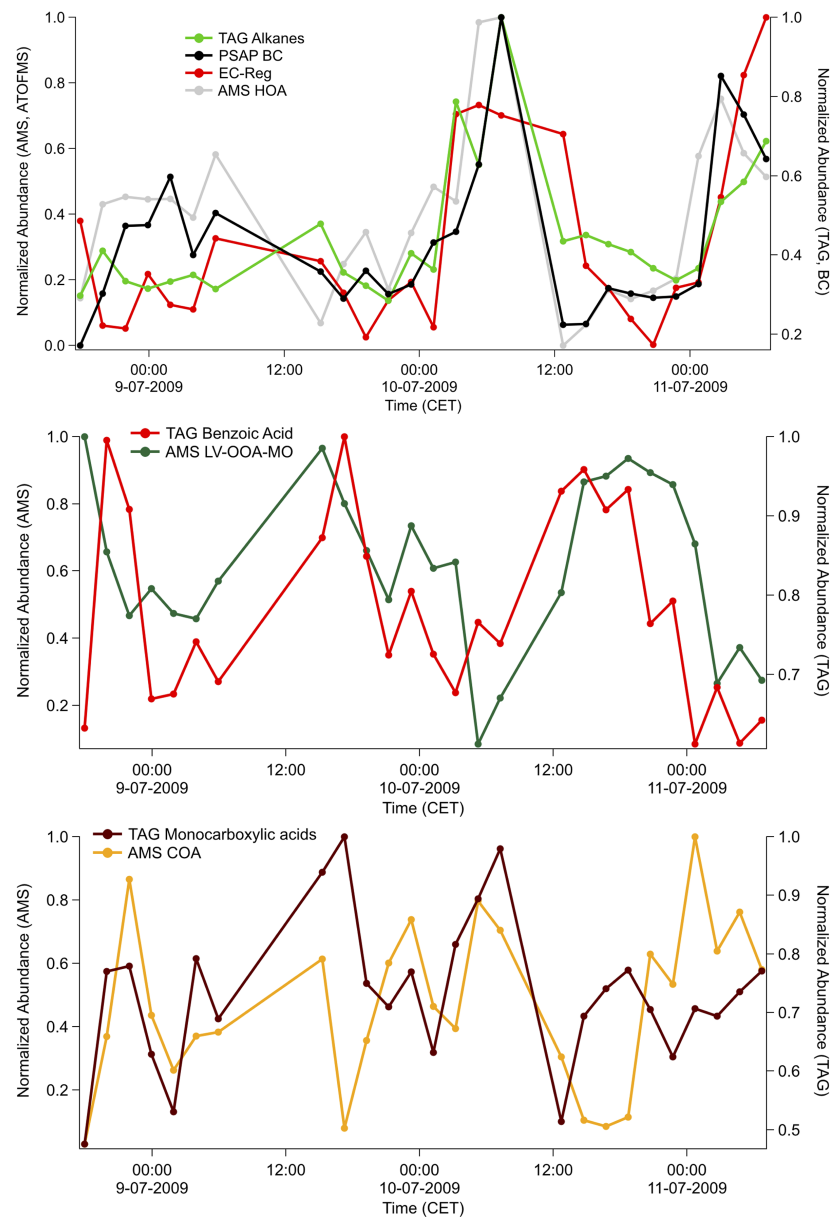

Figure 10. Time trends of major chemical classes measured by HR-ToFMS-TAG, shown together with the correlated external tracers from other techniques: (a) TAG alkanes (two combined factors) vs. PSAP BC, AMS HOA, ATOFMS NIT-Reg and EC-Reg; (b) TAG benzoic acid vs. AMS LV-OOA-MO; (c) TAG monocarboxylic acids (two combined factors) vs. AMS COA.

\subsection{Water-soluble organic composition from ${ }^{1}$ H-NMR analysis}

The results of NMR-factor analysis are presented in this section with the aim of comparison with PMF-AMS. The four-factor solution was the simplest one for which the three-factor analysis algorithms showed consistent results for both contributions and profiles. Other diagnostics $\left(Q / Q_{\exp }\right.$, Paatero and Tapper, 1994) did not provide clear transitions in the explained variations with increasing factor number (Fig. S8c). Figure 11 shows the spectra of the four factors:

- Factor 1: this factor is composed of aliphatic amines and unspeciated aliphatic compounds, and mainly occurs at night-time. Speciated amines, including DMA (dimethyl-), TMA (trimethyl-), DEA (diethyl-), TEA (triethyl-amine) are present in this factor. TMA was also detected by ATOFMS (see Sect. 3.5). The reason why 


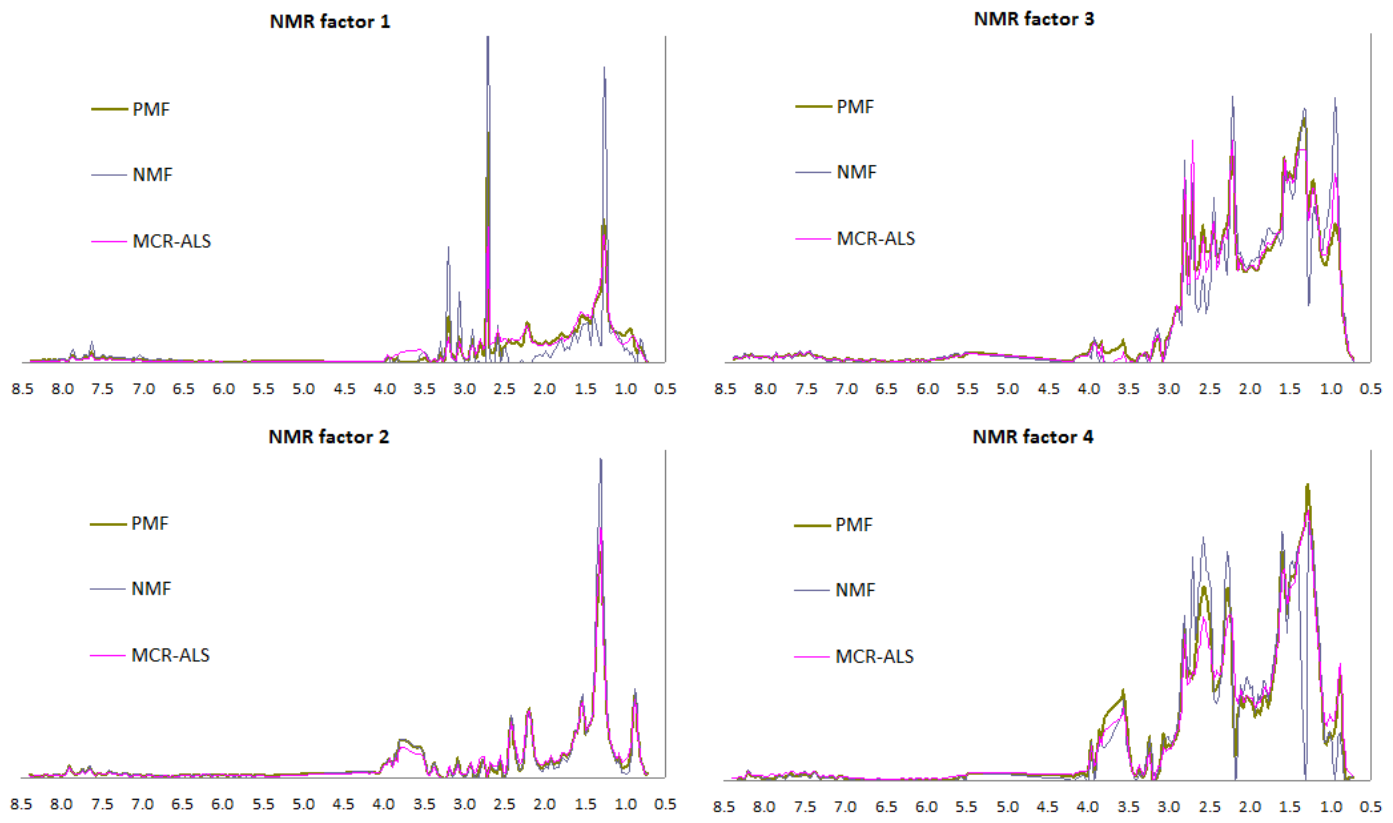

Figure 11. NMR spectral profiles of the four factors.

ATOFMS could not detect all the alkylamines observed by NMR spectroscopy cannot be easily explained, but there may be a sensitivity issue of ATOFMS with some chemical forms of the individual alkylamines, e.g. with counter ions not considered in the study of Angelino et al. (2001).

- Factor 2: this factor is composed of aliphatic alkanoic acids and oxo-acids (i.e. compounds characterised by linear chains with or without terminal methyls and oxo- or carboxyl substitutions). Although these compounds contribute in trace amounts and are also present in blanks and back-up filters, we believe these are genuine aerosol components, as concentrations are much higher in the sampled (front) filters.

- Factor 3 and Factor 4: these factors have spectral profiles characterised by the broad bands of polysubstituted aliphatic compounds with some aromatics, as expected for humic-like substances (HULIS) (Graber and Rudich, 2006). Both exhibit broad resonances in the range of the alkyl and substituted alkyl functional groups with very few specific peaks with the exception of that of MSA in the case of $F 3$ (singlet at $2.81 \mathrm{ppm}$ ). F4 shows greater amounts of alkoxy (HC-O) groups and of aliphatic groups highly substituted by oxo or carboxyl groups (region around $2.6 \mathrm{ppm}$ ) and lesser amounts of terminal methyls $(0.9 \mathrm{ppm})$ with respect to F3.

The comparison of time trends of the four WSOC factors with inorganic tracers and $\mathrm{BC}$ is summarised in Table 3. No factors correlate with sea salt. The best corre- lations are found for Factor 1 and ammonium nitrate and black carbon, and between the HULIS factor $F 4$ and nsssulfate. These findings indicate that Factor 1 originates from anthropogenic sources in the nocturnal boundary layer and that at least one of the HULIS factors is mainly of secondary origin from regional sources. Interestingly, BC shows positive correlations with the non-HULIS factors $(F 1+F 2$, mainly driven by $F 1$ ) and also with the composite HULIS factor $(F 3+F 4)$, suggesting that combustion sources contributed to WSOC both at night-time and in daytime conditions. Indeed the examination of BC time trends from PSAP (Fig. S5b) indicates the presence of two components: one associated with fresh emissions in the nocturnal stable layer, and a second one associated with the day-by-day accumulation in residual and mixing layers. Finally, the positive correlation of HULIS $F 4$ with $\mathrm{SO}_{2}$ is due to the tendency of very oxidised organic aerosols to show relative maxima in concentrations during daytime in the same manner as $\mathrm{SO}_{2}$, and also because of the greater HULIS levels in air masses having a continental component (PoV from W, N and E sectors) with respect to air masses with a marine component. When comparing the PMF-AMS results with those emerging from NMR-factor analysis, one should keep in mind that the latter was applied only to the water-soluble fraction of submicron aerosol organic compounds. For this reason, HOA should not be accounted for by the NMR characterisation. We have contrasted the time trends of NMR and (time-integrated) AMS factors and plotted them in Fig. 12a. The figure shows a good fit for AMS LV-OOA-LO (less oxidised) with NMR $F 3$ (HULIS with MSA) $\left(r^{2}=0.49\right)$ and a discrete fit of AMS SV-OOA with NMR $F 1$ (amine and 
Table 3. Correlation coefficient (as $r^{2}$, negative correlations in bold cells) of NMR factors for WSOC with submicron inorganic aerosol components and with trace gases. Only coefficients greater than 0.2 (as absolute value) are shown.

\begin{tabular}{|c|c|c|c|c|c|c|c|c|c|c|}
\hline & $\mathrm{nssCl}$ & $\mathrm{nssSO}_{4}^{=}$ & $\mathrm{NO}_{3}^{-}$ & $\mathrm{NH}_{4}^{+}$ & nssK & sea salt & $\mathrm{BC}$ & $\mathrm{SO}_{2}$ & NO & $\mathrm{NO}_{2}$ \\
\hline NMR $F 1$ & 0.25 & & 0.34 & 0.20 & & & 0.36 & & & \\
\hline NMR $F 2$ & & & & & & & & & & \\
\hline NMR $F 3$ & 0.28 & & & & & & & & & \\
\hline NMR $F 4$ & & 0.51 & & & & & & 0.28 & & 0.24 \\
\hline NMR $F 1+F 2$ (non HULIS) & & & & & & & 0.20 & & & 0.21 \\
\hline NMR $F 3+F 4$ (HULIS) & & & & & & & 0.28 & & & \\
\hline
\end{tabular}

a)
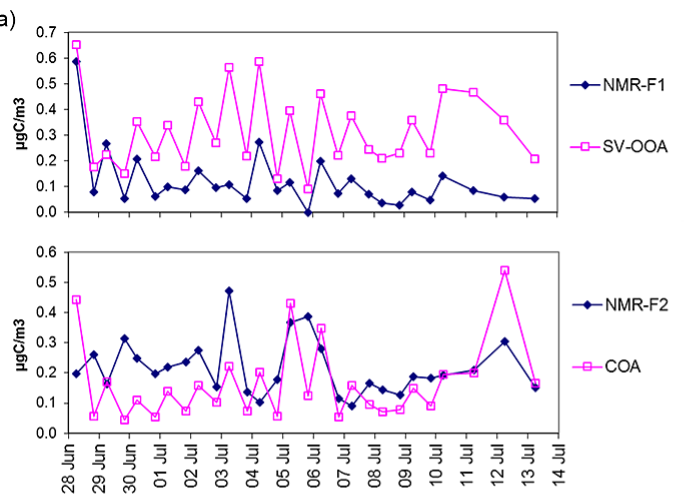

b)

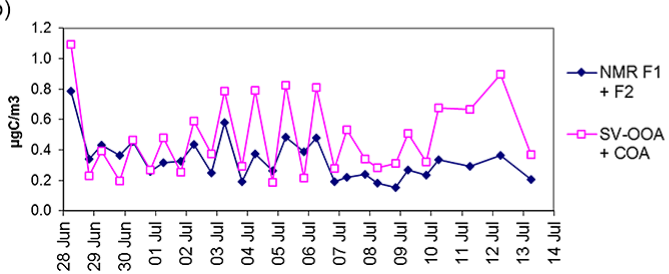

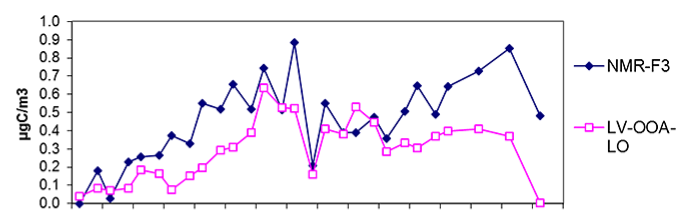
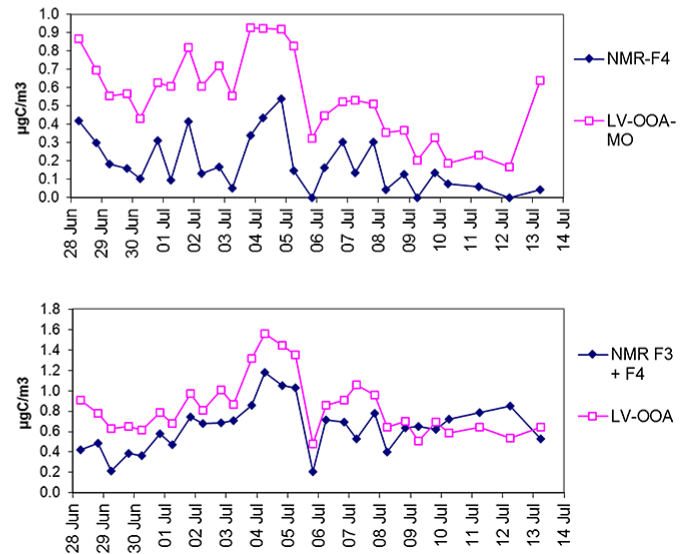

Figure 12. Comparison of time trends of NMR factors (PMF solution) and time-integrated AMS-factor concentrations. HOA is left out since it is not expected to contribute to WSOC. The $y$ axis reports concentrations in $\mu \mathrm{g} \mathrm{C} \mathrm{m}^{-3}$.

aliphatic) $\left(r^{2}=0.45\right)$. The best correlation is found between AMS LV-OOA-MO and NMR HULIS $F 4\left(r^{2}=0.65\right)$ although the AMS-factor concentrations are greater. The correlation of COA with NMR factors is weak. During the second part of the campaign, the concentrations of COA tend to follow those of NMR $F 2$ (alkanoic acid, $r^{2}=0.75$ after 5 July). A better match can be obtained by aggregating factors (Fig. 12b, Table 4), showing that there is a good overlap between the AMS total LV-OOA (composite of LO and MO) and the NMR HULIS $(F 3+F 4)$. This picture also shows that NMR $F 1+F 2$ are linked to the AMS SV-OOA + COA. Therefore, a clear split between OOA components forming from surface sources in the Po Valley (SV-OOA + COA and NMR Factors 1,2) and those characterising background air and correlating with sulfate (LV-OOAs and NMR factors 3, 4) is supported by the combination of the two spectroscopic techniques. As a final remark, if we assign NMR HULIS to AMS LV-OOAs and NMR Factor 1 (amines) to AMS SVOOA, then a correspondence between NMR Factor 2 (alka- noic acids) and AMS COA can be postulated. Alkanoic acids can actually form from oxidation of oleic acids and are commonly formed by meat cooking and food frying (Abdullahi et al., 2013), and likewise these include monocarboxylic acids found by the HR-TofMS-TAG (see Sect. 3.7).

\section{Discussion}

\subsection{Evolution of aerosol mixing state}

The above results show that, during the period of continental (PoV) air masses, the chemical processes governing the evolution of composition and mixing state of the aerosol at a polluted rural site are mainly triggered by the diurnal variability in the intensity of photochemistry and of atmospheric mixing as well as in the basic thermodynamic parameters $(T, \mathrm{RH})$. As a consequence, two different regimes of aerosol formation can be identified (Fig. 13): (a) at nighttime in the nocturnal surface layer ( $500 \mathrm{~m}$ a.s.l. $)$, and (b) in 
Table 4. Correlation between AMS and NMR factors. Only correlations $\left(r^{2}\right)$ higher than 0.2 are listed, if not left blank. All correlations shown are positive.

\begin{tabular}{|c|c|c|c|c|c|c|c|}
\hline & LV-OOA-MO & LV-OOA-LO & SV-OOA & $\mathrm{HOA}$ & $\mathrm{COA}$ & $\mathrm{LV}-\mathrm{OOA}-(\mathrm{LO}+\mathrm{MO})$ & $\mathrm{SV}-\mathrm{OOA}+\mathrm{COA}$ \\
\hline NMR $F 1$ & & & 0.45 & & 0.23 & & 0.41 \\
\hline NMR $F 2$ & & & & & & & \\
\hline NMR $F 3$ & & 0.49 & & & & & \\
\hline NMR $F 4$ & 0.61 & & & & & 0.53 & \\
\hline NMR $F 1+F 2$ (non-HULIS) & & & 0.40 & 0.22 & 0.39 & & 0.48 \\
\hline NMR $F 3+F 4$ (HULIS) & & & 0.25 & 0.31 & 0.26 & 0.51 & \\
\hline
\end{tabular}

daytime when processed aerosols are entrained from air layers aloft (500-2000 ma.s.l.). At night-time, due to the reduced mixing height, the aerosol composition is directly impacted by the emissions of primary particles from ground sources in the Po Valley and by the condensation of inorganic and organic secondary materials promoted by the cold and humid conditions. As a result, a complex aerosol mixing state is seen by the ATOFMS (step 1 in the figure): large particles rich in $\mathrm{BC}$ mixed or unmixed with semivolatile secondary material (the ATOFMS EC-Reg and NIT-Reg, respectively) coexist with smaller particles which can be explained as the result of fresh emissions in the Po Valley (NIT-Loc, $\mathrm{K}-\mathrm{CN}-$ amine and OC-SUL-NIT). The organic composition at this stage is characterised by poorly oxidised substances (the AMS HOA, COA and SV-OOA; the NMR alkyl-amines; the alkanes and alkanoic acids from TAG) reflecting the impact of fresh aerosol sources. During the day, the drop in RH, the temperature increase and the dilution of the aerosol in a deeper mixing layer leads to the evaporation of semivolatile compounds, such as ammonium nitrate (but a similar process affecting the AMS SV-OOA, HOA and COA can be postulated). At the same time, the condensation of new oxidised secondary compounds (traced by the benzoic acid observed by TAG) takes place. As a result, many of the particles rich in ammonium nitrate (NIT-Reg) get denuded and the ATOFMS starts to measure particles containing merely non-volatile compounds, such as EC mixed with sulfate (the SUL-Reg) (step 2). Particles rich in EC and with unknown coating (the EC-Reg type) are dispersed in the mixing layer but also entrained from residual layers (step 3 ). The daytime condensation of ammonium sulfate and of highly oxygenated SOA tends to decrease the mass fraction on $\mathrm{BC}$ in the aerosol (step 4). When condensational growth occurred on particles which originally did not contain a $\mathrm{BC}$ core, like particles formed by nucleation or organic particles emitted by some combustion sources (e.g. Liu et al., 2014), then aerosols with secondary compounds externally mixed with $\mathrm{BC}$ were produced, contributing to the non-refractory mass measured by the HR-ToF-AMS but poorly seen or completely missed by the SP-AMS. In daytime, particles are entrained from residual layers, including elevated layers bringing aerosols that have experienced long-range transport (step 5), and after sun-

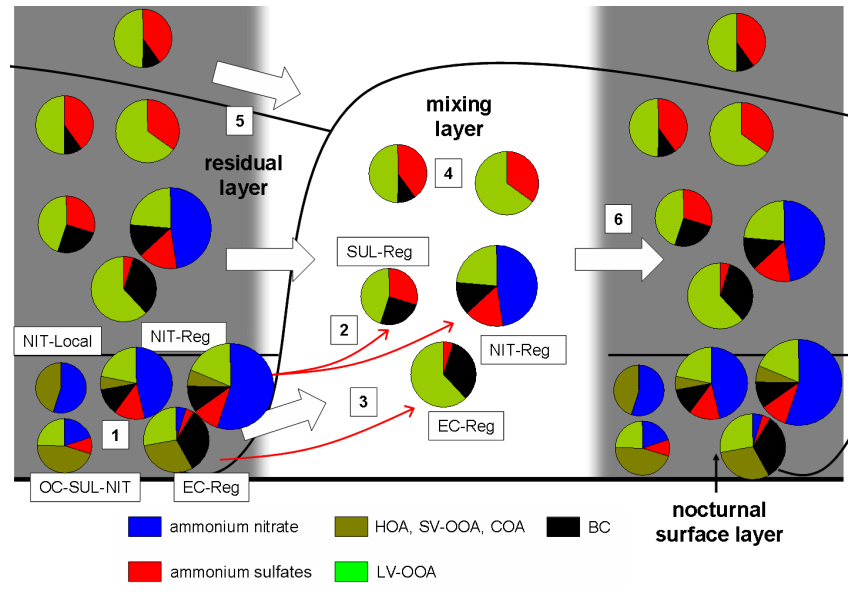

Figure 13. Schematic representation of the evolution of accumulation mode aerosol chemical composition and mixing state during the field campaign. Grey and white areas represent night and day hours. The vertical axis is the elevation above ground level. The thickness of the nocturnal surface layer is approximately $100-500 \mathrm{~m}$. The height of the daytime mixing layer is $1500-2000 \mathrm{~m}$ above the ground. Further explanations in the text.

set they are also exported in the residual layers (step 6). The occurrence of aerosol particles not carrying a BC core in aged air masses is consistent with the recent findings of Laborde et al. (2013) in the Paris area.

The impact of these simple meteorological factors on aerosol dynamics was evident throughout the campaign except for the west-type air masses. However, even by restricting our analysis to the case of continental air masses $(\mathrm{PoV})$, the actual impact of the meteorological factors qualitatively depicted in Fig. 13 varied day by day following the changes in weather conditions (stagnation vs. more ventilation). To evaluate the effect of changing weather conditions on EC mixing state, we have compared ATOFMS data summarised for the first week (28 June-4 July) characterised by more stable conditions with the average concentrations for the (more ventilated) last days of the experiment (10-12 July). We expressed the EC mixing state using indexes obtained by compacting the ATOFMS data into a few main categories (Fig. 14): soot with unknown coating 

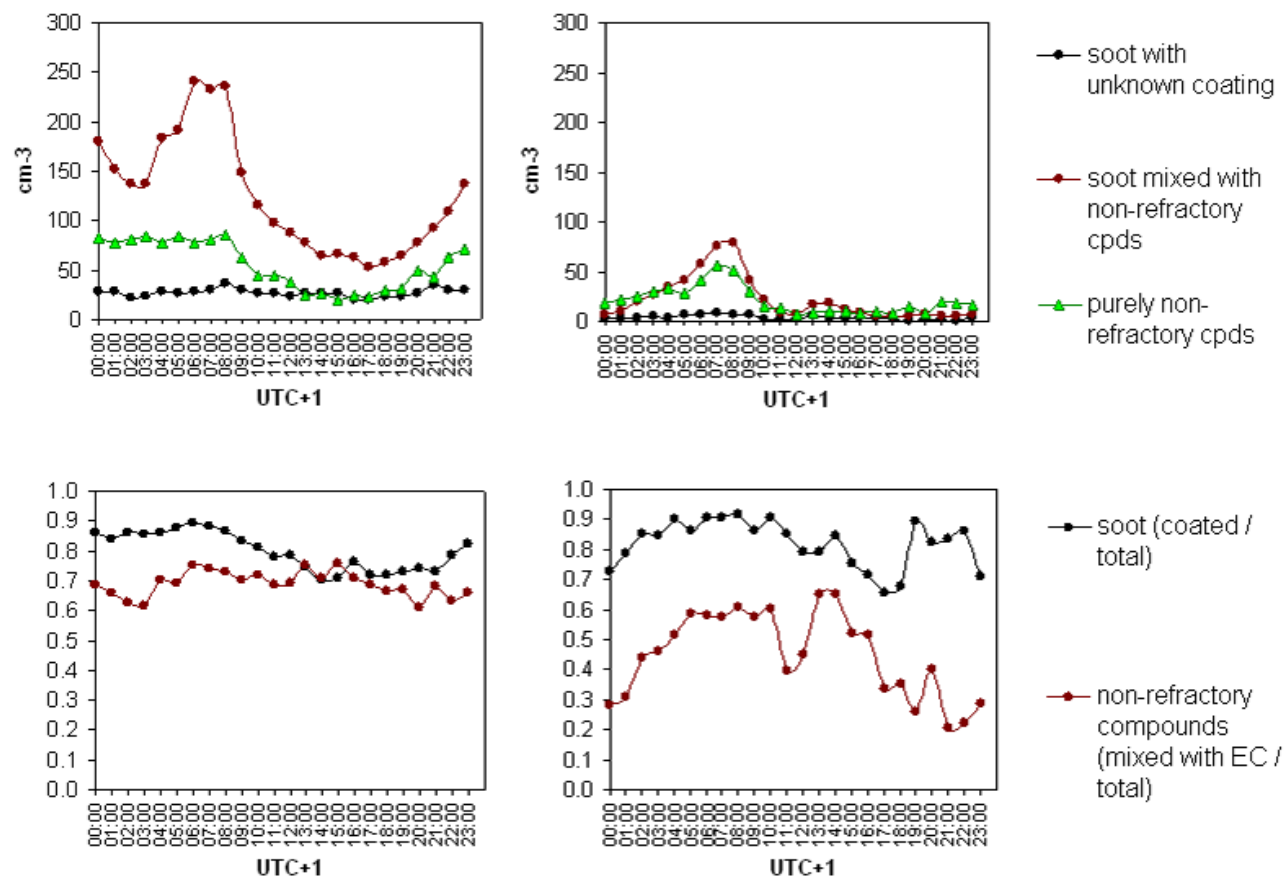

Figure 14. Upper panels: summary of the diurnal cycles of main ATOFMS particle populations: soot with unknown coating (EC-Reg), soot mixed with non-refractory components (NIT-Reg + SUL-Reg + NIT-Loc/Reg), purely non-refractory particles (i.e. unmixed with soot) (NIT-Loc $+\mathrm{K}-\mathrm{CN}-$ Amine + OC-SUL-NIT). Lower panels: concentration ratios between the main ATOFMS particle populations. Coated soot refers here to the fraction of soot-containing particles with an ATOFMS-detected coating. The two panels on the left refer to the first week of campaign (28 June-4 July), while the ones on the left cover the three last days of the experiment (8-12 July).

(EC-Reg), coated soot (i.e. soot mixed with non-refractory components) (NIT-Reg + SUL-Reg + NIT-Loc/Reg), purely non-refractory particles (i.e. unmixed with soot) (NITLoc $+\mathrm{K}-\mathrm{CN}-$ Amine + OC-SUL-NIT). Clearly, the concentrations of soot-containing particles (both coated and with unknown coating) were much lower in the end of the period than during the first week of more polluted conditions, while the concentrations of the particles made of purely nonrefractory components changed to a much lesser extent between the two periods. As a result, the fraction of the particles carrying non-refractory compounds which is actually mixed with EC was $70 \%$ during the first period characterised by stagnant conditions and recirculation of pollutants, while it dropped to $30-50 \%$ during the second, cleaner period. Since we cannot exclude that the ATOFMS did not measure the totality of the particles unmixed with $\mathrm{BC}$, the above ratios must be considered as upper limits. These results indicate that the aerosol non-refractory compounds were largely externally mixed with $\mathrm{BC}$, especially during the less polluted conditions encountered during the last part of the experiment.

\subsection{Effect of PBL meteorology on aerosol organic composition}

The two regimes of aerosol formation schematically depicted in Fig. 13 imply two different source footprints: night- time-early morning aerosols, accumulating in the nocturnal surface layer or in an incipient mixing layer, must originate from ground-level sources at low elevation in the Po Valley basin (hence mainly anthropogenic), while the aerosol entrained in the middle of the day and afternoon hours can be impacted by sources much further away. We dedicate this final part of the discussion to investigate possible footprints for the oxidised secondary aerosols (and of recirculated primary aerosols) which dominate the composition in daytime. Ozone and (at least partly) LV-OOA are photochemically formed, but the actual oxidation processes responsible for their formation can occur in situ in the Po Valley sector enclosing the station, or elsewhere with the products being mainly transported to SPC. The lidar-ceilometer data suggest that aerosols in residual layers are clearly impacted by recirculation of particles (and of their precursors) lifted from ground-level sources during the mixing layer deepening on the day before. In order to test this hypothesis, we recorded the equivalent potential temperature $\left(\theta_{\mathrm{e}}\right)$ in residual layers at $850 \mathrm{hPa}(\sim 1500 \mathrm{~m}$ a.s.l. $)$, which can be used to trace boundary layer air during the conditions of the experiment. Indeed, meteorological models and reanalysis data (ERA-interim) for typical summertime conditions over Italy clearly show that warm humid air is lifted to the $850 \mathrm{hPa}$ level from the surface level in daytime through thermal convection amplified by orographic transport along the Apennines 
and the Alps ridges. Equivalent potential temperature data show that warm humid air persists overnight at $850 \mathrm{hPa}$, undergoes some transport according to wind regimes and can be eventually recirculated the day after. To investigate the effect of such atmospheric dynamics on the OOA concentrations in the rural Po Valley, we compared $\theta_{\mathrm{e}}$ in residual layers in the night over SPC (from radiosoundings at 00:00 UTC) with the LV-OOA concentrations on the day after. We found a moderately positive correlation $\left(r^{2}=0.38\right)$ (Fig. 15). The correlation is degraded by the sample of 5 July, when intense precipitation and aerosol scavenging occurred: on that day, a conservative behaviour can be assumed neither for water vapour nor for aerosols. If we omit this day, the correlation is much more robust $\left(r^{2}=0.65\right)$. We can therefore safely state that LV-OOA are mainly associated with recirculated PBL air that had lifted over continental areas, rather than from transport in the free troposphere from very remote sources. To further investigate the possible extension of the footprint of the regional source footprint of the LVOOA, we report maps of $\theta_{\mathrm{e}}$ obtained from ERA-interim for the great Alpine region and for northern Italy in night-time hours and for specific periods of the campaign (Fig. S12). These will show the horizontal extension of residual layers influenced by boundary layer sources under varying meteorological regimes. From the first days of the campaign until 4 July, high nocturnal $\theta_{\mathrm{e}}$ are found throughout the great Alpine region and neighbouring areas, which could act as source areas for the precursors of sulfate and SOA, especially in the very first days (28-29 June), when the main circulation was from the north, i.e. from central Europe and across the Alps. The intensification of convection with consequent lifting of PBL air in the region was observed progressively until 4 July and this corresponds to the increase of aerosol extinction observed by the ceilometer in these days. In the days of westerly flows (8 July is shown in the figure), the convection of warm humid air is completely switched off in the areas north of the Alps, which are directly influenced by the fresh Atlantic air masses. Conversely, warm air persists over the Po Valley meaning that convection along the Apennines and over warm Mediterranean basins is still active. On 11 July, convection is strongly reduced almost everywhere and we observe in this day a general minimum of $\theta_{\mathrm{e}}$ in residual layers. Notice that this is also the day showing minimum concentrations of odd oxygen $\left(\mathrm{O}_{\mathrm{x}}\right)$ and of total LV-OOAs. On 12 July, we observe some recovery in the western sectors, but the Po Valley is influenced by an easterly flow, i.e. from areas where $\theta_{\mathrm{e}}$ is still quite low. Now, the analysis of the temporal trends of the HR-ToF-AMS LV-OOA factors indicate that the most oxidised (LV-OOA-MO) are found on days characterised by continental air masses (from $\mathrm{N}$ like 28 June, NW like 3 July or E like 12 July) and in higher concentrations when also $\theta_{\mathrm{e}}$ over central Europe (the great Alpine region and neighbouring areas) is high. Conversely, the concentrations of less oxidised low-volatility OOA (LVOOA-LO) recover against those of LV-OOA-MO when con-

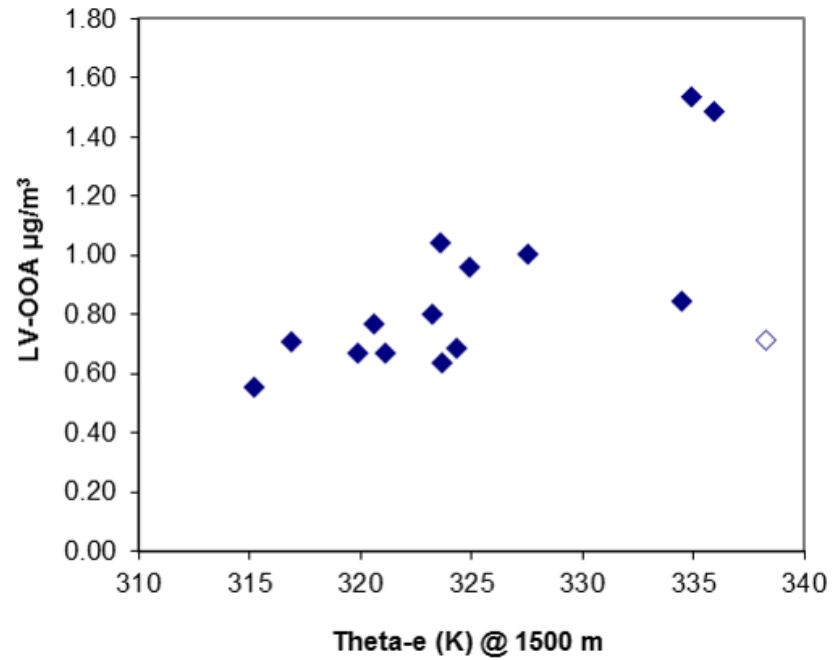

Figure 15. Scatter plot between equivalent potential temperature and total LV-OOA $(\mathrm{LO}+\mathrm{MO})$. The white symbol corresponds to the 5 July sample.

vection starts intensively over the Po Valley (3 July), and especially during the days of westerly flow (8 July) when the source areas of PBL air in central Europe are switched off, while convection (and lifting of gases and particles) is still active in northern Italy and in the Ligurian Sea. These observations support the concept of the two classes of LV-OOA (and of NMR HULIS) representing two endmembers of an atmospheric ageing process, with one more local and less processed, and another more regional and more processed. In particular, the LV-OOA-LO (and NMR F3) are associated with recirculated PBL air lifted over northern Italy, while the LV-OOA-MO (and NMR F4) originate from PBL air lifted over a wider continental area encompassing the great Alpine region and central Europe. The oxidation level can therefore be put in relation to the extent of transport.

Finally, the analysis of $\theta_{\mathrm{e}}$ maps also provides an explanation for why the ratio between local and regional OOAs is higher in days where back-trajectories indicate a longrange transport in westerly air masses (8-9 July): on those days, convection and lifting of aerosol and precursors were strongly reduced at the regional scale. These results indicate that the classification of aerosols based on back-trajectory analysis should be done with caution in areas characterised by complex orography and boundary layer dynamics.

\section{Conclusions}

In this experiment we performed sophisticated investigations of the aerosol chemical composition and mixing state using modern aerosol spectrometers at a continental regional background site. Previous field experiments using analogous experimental approaches focused on environments 
characterised by a localised big urban source, or were performed at coastal sites where there is a consistent air flow from in-land large emission sites to the ocean (Chebogue Point, in the frame of NEAQS - ITCT). In such environments, it is possible to link aerosol composition to the travel time from the source areas (e.g. Doran et al., 2007). Most of the time, however, one measuring station can be surrounded by anthropogenic and natural sources in any directions. Under such, more common, circumstances, the critical variables are the presence of geographical barriers (mountain ridges) and, most importantly, the height of the mixing layer, which in turn regulates the entrainment of aerosols transported in the elevated layers. We have shown in this study that anthropogenic aerosols can accumulate in geographical basins (like the Po Valley) in the presence of atmospheric stratification, but in typical summertime daytime conditions, with a 1500-2000 m thick PBL, transport can occur even across a tall mountain chain like the Alps. Our organic source apportionment results indicate that anthropogenic aerosols accumulating in the lower layers overnight accounted for $38 \%$ $(\mathrm{HOA}+\mathrm{COA}+\mathrm{SV}-\mathrm{OOA})$ of OA mass on average, while another $21 \%$ was accounted for by more aged aerosols (LVOOA-LO) recirculated in residual layers but still originating in northern Italy, and finally a considerable fraction (41\%) was due to aged aerosols (LV-OOA-MO) from transalpine transport. The dynamic of the PBL also affects the aerosol compounds mixing state. At evening/night, when the atmosphere was stratified, the impact from fresh, diverse primary emissions (traffic, possibly cooking) increased the extent of external mixing and such increase was only partially compensated by the condensation of semivolatile compounds (ammonium nitrate, amines) which took place in the coldest hours of the day (late night) and after dawn when photochemistry starts while $\mathrm{NO}_{\mathrm{x}}$ concentrations are still high. During the day, the evaporation of particles made of semivolatile components led to a major loss of fine-mode nitrate particles. At the same time, the entrainment of residual layers brought aged BC particles which originated from the recirculation of Po Valley polluted air. In the last part of the campaign, which was less polluted and the black carbon concentrations small $\left(0.2-0.6 \mu \mathrm{g} \mathrm{m}^{-3}\right)$, about half of the accumulation mode particles measured by the ATOFMS were unmixed with EC, i.e. made purely of non-refractory components. In the same period, the SP-AMS showed much greater ratios between $\mathrm{BC}$ and the non-refractory components than suggested by the comparison of the PSAP BC concentrations with the HR-ToF-AMS total concentrations of sulfate, nitrate and organic matter. An accurate quantification of the mass concentrations of non-refractory compounds externally mixed with BC could not be achieved because of the RIE of the aerosol chemical compounds was not calibrated in the SP-AMS. However, our data seem to indicate a significant fraction of sulfate, nitrate and organic matter externally mixed with BC both at night-time and in daytime, and which cannot be reconciled with accounting for the uncertainties in the MAC and RIE parameters. In conclusion, a full internal mixing between $\mathrm{BC}$ and the non-refractory aerosol chemical components could be observed neither under the impact of fresh pollution sources nor in the aged continental air masses.

\section{The Supplement related to this article is available online at doi:10.5194/acp-14-12109-2014-supplement.}

Acknowledgements. This work was funded by European integrated project on aerosol cloud climate and air quality interactions (no. 036833-2, EUCAARI). The ERA-Interim data were kindly provided by Silvio Davolio (CNR-ISAC). Data analysis was co-funded by the project PEGASOS (EC FP7-ENV-2010-265148) and by the project SUPERSITO of Region Emilia-Romagna. ACCENT + is also gratefully acknowledged. Finally, Emanuela Finessi (CNR-ISAC, now at University of York) is also gratefully acknowledged for the precious work in aerosol filter collection in the field. Manuel Dall'Osto and Roy M. Harrison thank the UK National Centre for Atmospheric Science for financial support. Work by Georg Stange, K. Michl and R. T. Wilhelm (all DWD) on gas-phase constituents is greatly acknowledged.

Edited by: Y. Cheng

\section{References}

Abdullahi, K. L., Delgado-Saborit, J. M., and Harrison, R. M.: Emissions and indoor concentrations of particulate matter and its specific chemical components from cooking: a review, Atmos. Environ., 71, 260-294, 2013.

Aiken, A. C., Salcedo, D., Cubison, M. J., Huffman, J. A., DeCarlo, P. F., Ulbrich, I. M., Docherty, K. S., Sueper, D., Kimmel, J. R., Worsnop, D. R., Trimborn, A., Northway, M., Stone, E. A., Schauer, J. J., Volkamer, R. M., Fortner, E., de Foy, B., Wang, J., Laskin, A., Shutthanandan, V., Zheng, J., Zhang, R., Gaffney, J., Marley, N. A., Paredes-Miranda, G., Arnott, W. P., Molina, L. T., Sosa, G., and Jimenez, J. L.: Mexico City aerosol analysis during MILAGRO using high resolution aerosol mass spectrometry at the urban supersite (T0) - Part 1: Fine particle composition and organic source apportionment, Atmos. Chem. Phys., 9, 6633-6653, doi:10.5194/acp-9-6633-2009, 2009.

Allan, J. D., Jimenez, J. L., Williams, P. I., Alfarra, M. R., Bower, K. N., Jayne, J. T., Coe, H., and Worsnop, D. R.: Quantitative sampling using an Aerodyne aerosol mass spectrometer - 1. Techniques of data interpretation and error analysis, J. Geophys. Res.Atmos., 108, 4090, doi:10.1029/2002JD002358, 2003.

Allan, J. D., Delia, A. E., Coe, H., Bower, K. N., Alfarra, M. R., Jimenez, J. L., Middlebrook, A. M., Drewnick, F., Onasch, T. B., Canagaratna, M. R., Jayne, J. T., and Worsnop, D. R.: A generalised method for the extraction of chemically resolved mass spectra from aerodyne aerosol mass spectrometer data, J. Aerosol Sci., 35, 909-922, doi:10.1016/j.jaerosci.2004.02.007, 2004.

Allan, J. D., Williams, P. I., Morgan, W. T., Martin, C. L., Flynn, M. J., Lee, J., Nemitz, E., Phillips, G. J., Gallagher, M. W., and Coe, 
H.: Contributions from transport, solid fuel burning and cooking to primary organic aerosols in two UK cities, Atmos. Chem. Phys., 10, 647-668, doi:10.5194/acp-10-647-2010, 2010.

Angelino, S., Suess, D. T., and Prather, K. A.: Formation of aerosol particles from reactions of secondary and tertiary alkylamines: characterization by aerosol time-of-flight mass spectrometry, Environ. Sci. Technol., 35, 3130-3138, 2001.

Berresheim, H., Elste, T., Plass-Dülmer, C., Eisele, F. L., and Tanner, D. J.: Chemical ionization mass spectrometer for long-term measurements of atmospheric $\mathrm{OH}$ and $\mathrm{H}_{2} \mathrm{SO}_{4}$, Int. J. Mass Spectrom., 202, 91-109, 2000.

Bond, T. C., Anderson, T. L., and Campbell, D.: Calibration and intercomparison of filter-based measurements of visible light absorption by aerosols, Aerosol Sci. Tech., 30, 582-600, 1999.

Canagaratna, M. R., Jayne, J. T., Ghertner, D. A., Herndon, S., Shi, Q., Jimenez, J. L., Silva, P. J., Williams, P., Lanni, T., Drewnick, F., Demerjian, K. L., Kolb, C. E., and Worsnop, D. R.: Chase studies of particulate emissions from in-use New York city vehicles, Aerosol Sci. Tech., 38, 555-573, 2004.

Canagaratna, M. R., Jayne, J. T., Jimenez, J. L., Allan, J. D., Alfarra, M. R., Zhang, Q., Onasch, T. B., Drewnick, F., Coe, H., Middlebrook, A., Delia, A., Williams, L. R., Trimborn, A. M., Northway, M. J., DeCarlo, P. F., Kolb, C. E., Davidovits, P., and Worsnop, D. R.: Chemical and microphysical characterization of ambient aerosols with the aerodyne aerosol mass spectrometer, Mass Spectrom. Rev., 26, 185-222, 2007.

Carbone, C., Decesari, S., Mircea, M., Giulianelli, L., Finessi, E., Rinaldi, M., Fuzzi, S., Marinoni, A., Duchi, R., Perrino, C., Sargolini, T., Varde, M., Sprovieri, F., Gobbi, G. P., Angelini, F., and Facchini, M. C.: Size-resolved aerosol chemical composition over the Italian Peninsula during typical summer and winter conditions, Atmos. Environ., 44, 5269-5278, 2010.

Chen, Q., Farmer, D. K., Rizzo, L. V., Pauliquevis, T., Kuwata, M., Karl, T. G., Guenther, A., Allan, J. D., Coe, H., Andreae, M. O., Pöschl, U., Jimenez, J. L., Artaxo, P., and Martin, S. T.: Finemode organic mass concentrations and sources in the Amazonian wet season (AMAZE-08), Atmos. Chem. Phys. Discuss., 14, 16151-16186, doi:10.5194/acpd-14-16151-2014, 2014.

Dall'Osto, M. and Harrison, R. M.: Chemical characterisation of single airborne particles in Athens (Greece) by ATOFMS, Atmos. Environ., 40, 7614-7631, 2006.

Dall'Osto, M., Harrison, R. M., Coe, H., Williams, P. I., and Allan, J. D.: Real time chemical characterization of local and regional nitrate aerosols, Atmos. Chem. Phys., 9, 3709-3720, doi:10.5194/acp-9-3709-2009, 2009.

Dall'Osto, M., Querol, X., Alastuey, A., Minguillon, M. C., Alier, M., Amato, F., Brines, M., Cusack, M., Grimalt, J. O., Karanasiou, A., Moreno, T., Pandolfi, M., Pey, J., Reche, C., Ripoll, A., Tauler, R., Van Drooge, B. L., Viana, M., Harrison, R. M., Gietl, J., Beddows, D., Bloss, W., O'Dowd, C., Ceburnis, D., Martucci, G., Ng, N. L., Worsnop, D., Wenger, J., Mc Gillicuddy, E., Sodeau, J., Healy, R., Lucarelli, F., Nava, S., Jimenez, J. L., Gomez Moreno, F., Artinano, B., Prévôt, A. S. H., Pfaffenberger, L., Frey, S., Wilsenack, F., Casabona, D., Jiménez-Guerrero, P., Gross, D., and Cots, N.: Presenting SAPUSS: Solving Aerosol Problem by Using Synergistic Strategies in Barcelona, Spain, Atmos. Chem. Phys., 13, 8991-9019, doi:10.5194/acp-13-89912013, 2013.
DeCarlo, P. F., Kimmel, J. R., Trimborn, A., Northway, M. J., Jayne, J. T., Aiken, A. C., Gonin, M., Fuhrer, K., Horvath, T., Docherty, K. S., Worsnop, D. R., and Jimenez, J. L.: Field-deployable, high-resolution, time-of-flight aerosol mass spectrometer, Anal. Chem., 78, 8281-8289, 2006.

Decesari, S., Finessi, E., Rinaldi, M., Paglione, M., Fuzzi, S., Stephanou, E. G., Tziaras, T., Spyros, A., Ceburnis, D., O’Dowd, C., Dall'Osto, M., Harrison, R. M., Allan, J., Coe, H., and Facchini, M. C.: Primary and secondary marine organic aerosols over the North Atlantic Ocean during the MAP experiment, J. Geophys. Res., 116, D22210, doi:10.1029/2011JD016204, 2011.

Deserti, M., Savoia, E., Cacciamani, C., Golinelli, M., Kerschbaumer, A., Leoncini, G., Selvini, A., Paccagnella, T., and Ribaldi, S.: Operational meteorological pre-processing at EmiliaRomagna ARPA Meteorological Service as a part of a decision support system for air quality management, Int. J. Environ. Pollut., 16, 571-582, 2010.

Di Giuseppe, F., Riccio, A., Caporaso, L., Bonafè, G., Gobbi, G. P., and Angelini, F.: Automatic detection of atmospheric boundary layer height using ceilometer backscatter data assisted by a boundary layer model, Q. J. Roy. Meteor. Soc., 138, 649-663, doi:10.1002/qj.964, 2012.

Docherty, K. S., Stone, E. A., Ulbrich, I. M., DeCarlo, P. F., Snyder, D. C., Schauer, J. J., Peltier, R. E., Weber, R. J., Murphy, S. M., Seinfeld, J. H., Eatough, D. J., and Jimenez, J. L.: Apportionment of primary and secondary organic aerosols in Southern California during the 2005 Study of Organic Aerosols in Riverside (SOAR), Environ. Sci. Technol., 42, 7655-7662, doi:10.1021/es8008166, 2008

Doran, J. C., Barnard, J. C., Arnott, W. P., Cary, R., Coulter, R., Fast, J. D., Kassianov, E. I., Kleinman, L., Laulainen, N. S., Martin, T., Paredes-Miranda, G., Pekour, M. S., Shaw, W. J., Smith, D. F., Springston, S. R., and Yu, X.-Y.: The T1-T2 study: evolution of aerosol properties downwind of Mexico City, Atmos. Chem. Phys., 7, 1585-1598, doi:10.5194/acp-7-1585-2007, 2007.

Drewnick, F., Hings, S. S., DeCarlo, P., Jayne, J. T., Gonin, M., Fuhrer, K., Weimer, S., Jimenez, J. L., Demerjian, K. L., Borrmann, S., and Worsnop, D. R.: A new time-of-flight aerosol mass spectrometer (TOF-AMS) - instrument description and first field deployment, Aerosol Sci. Tech., 39, 637-658, doi:10.1080/02786820500182040, 2005.

Fehsenfeld, F. C., Ancellet, G., Bates, T. S., Goldstein, A. H., Hardesty, R. M., Honrath, R., Law, K. S., Lewis, A. C., Leaitch, R., McKeen, S., Meagher, J., Parrish, D. D., Pszenny, A. A. P., Russell, P. B., Schlager, H., Seinfeld, J., Talbot, R., and Zbinden, R.: International Consortium for Atmospheric Research on Transport and Transformation (ICARTT): North America to Europe overview of the 2004 summer field study, J. Geophys. Res., 111, D23S01, doi:10.1029/2006JD007829, 2006.

Gard, E., Mayer, J. E., Morrical, B. D., Dienes, T., Fergenson, D. P., and Prather, K. A.: Real-time analysis of individual atmospheric aerosol particles: design and performance of a portable ATOFMS, Anal. Chem., 69, 4083-4091, 1997.

Gard, E. E., M. J. Kleeman, D. S. Gross, L. S. Hughes, J. O. Allen, B. D. Morrical, D. P. Fergenson, T. Dienes, M. E. Galli, R. J. Johnson, G. R. Cass, and K. A. Prather, Direct observation of heterogeneous chemistry in the atmosphere, Science, 279, 1184-1187, 1998. 
Gilge, S., Plass-Duelmer, C., Fricke, W., Kaiser, A., Ries, L., Buchmann, B., and Steinbacher, M.: Ozone, carbon monoxide and nitrogen oxides time series at four alpine GAW mountain stations in central Europe, Atmos. Chem. Phys., 10, 12295-12316, doi:10.5194/acp-10-12295-2010, 2010.

Giorio, C., Tapparo, A., Dall'Osto, M., Harrison M.; Beddows, D. C. S., Di Marco, C. and Nemitz, E.: Comparison of three techniques for analysis of data from an Aerosol Time-of-Flight Mass Spectrometer, Atmos. Environ., 61, 316-326, 2012.

Graber, E. R. and Rudich, Y.: Atmospheric HULIS: How humic-like are they? A comprehensive and critical review, Atmos. Chem. Phys., 6, 729-753, doi:10.5194/acp-6-729-2006, 2006.

Harrison, R. M., Dall'Osto, M., Beddows, D. C. S., Thorpe, A. J., Bloss, W. J., Allan, J. D., Coe, H., Dorsey, J. R., Gallagher, M., Martin, C., Whitehead, J., Williams, P. I., Jones, R. L., Langridge, J. M., Benton, A. K., Ball, S. M., Langford, B., Hewitt, C. N., Davison, B., Martin, D., Petersson, K. F., Henshaw, S. J., White, I. R., Shallcross, D. E., Barlow, J. F., Dunbar, T., Davies, F., Nemitz, E., Phillips, G. J., Helfter, C., Di Marco, C. F., and Smith, S.: Atmospheric chemistry and physics in the atmosphere of a developed megacity (London): an overview of the REPARTEE experiment and its conclusions, Atmos. Chem. Phys., 12, 3065-3114, doi:10.5194/acp-12-3065-2012, 2012.

Hayes, P. L., Ortega, A. M., Cubison, M. J., Froyd, K. D., Zhao, Y., Cliff, S. S., Hu, W. W., Toohey, D. W., Flynn, J. H., Lefer, B. L., Grossberg, N., Alvarez, S., Rappenglück, B., Taylor, J. W., Allan, J. D., Holloway, J. S., Gilman, 5 J. B., Kuster, W. C., de Gouw, J. A., Massoli, P., Zhang, X., Liu, J., Weber, R. J., Corrigan, A. L., Russell, L. M., Isaacman, G., Worton, D. R., Kreisberg, N. M., Goldstein, A. H., Thalman, R., Waxman, E. M., Volkamer, R., Lin, Y. H., Surratt, J. D., Kleindienst, T. E., Offenberg, J. H., Dusanter, S., Griffith, S., Stevens, P. S., Brioude, J., Angevine, W. M., and Jimenez, J. L.: Organic aerosol composition and sources in Pasadena, California, during the 2010 CalNex campaign, J. Geophys. Res., 118, 9233-9257, doi:10.1002/jgrd.50530, 2013.

Healy, R. M., Sciare, J., Poulain, L., Crippa, M., Wiedensohler, A., Prévôt, A. S. H., Baltensperger, U., Sarda-Estève, R., McGuire, M. L., Jeong, C.-H., McGillicuddy, E., O’Connor, I. P., Sodeau, J. R., Evans, G. J., and Wenger, J. C.: Quantitative determination of carbonaceous particle mixing state in Paris using single-particle mass spectrometer and aerosol mass spectrometer measurements, Atmos. Chem. Phys., 13, 9479-9496, doi:10.5194/acp13-9479-2013, 2013.

Henne, S., Furger, M., Nyeki, S., Steinbacher, M., Neininger, B., de Wekker, S. F. J., Dommen, J., Spichtinger, N., Stohl, A., and Prévôt, A. S. H.: Quantification of topographic venting of boundary layer air to the free troposphere, Atmos. Chem. Phys., 4, 497-509, doi:10.5194/acp-4-497-2004, 2004.

Jaumot, J., Gargallo, R., de Juan, A., and Tauler, R.: A graphical userfriendly interface for MCR_ALS: a new tool for multivariate curve resolution in MATLAB, Chemometr. Intell. Lab., 76, 101-110, doi:10.1016/j.chemolab.2004.12.007, 2005.

Jayne, J. T., Leard, D. C., Zhang, X. F., Davidovits, P., Smith, K. A., Kolb, C. E., and Worsnop, D. R.: Development of an aerosol mass spectrometer for size and composition analysis of submicron particles, Aerosol Sci. Tech., 33, 49-70, 2000.

Jimenez, J. L., Jayne, J. T., Shi, Q., Kolb, C. E., Worsnop, D. R., Yourshaw, I., Seinfeld, J. H., Flagan, R. C., Zhang, X. F., Smith, K. A., Morris, J. W., and Davidovits, P.: Ambient aerosol sampling using the Aerodyne Aerosol Mass Spectrometer, J. Geophys. Res.-Atmos., 108, 8425, doi:10.1029/2001JD001213, 2003.

Jimenez, J. L., Canagaratna, M. R., Donahue, N. M., Prevot, A. S. H., Zhang, Q., Kroll, J. H., DeCarlo, P. F., Allan, J. D., Coe, H., Ng, N. L., Aiken, A. C., Docherty, K. S., Ulbrich, I. M., Grieshop, A. P., Robinson, A. L., Duplissy, J., Smith, J. D., Wilson, K. R., Lanz, V. A., Hueglin, C., Sun, Y. L., Tian, J., Laaksonen, A., Raatikainen, T., Rautiainen, J., Vaattovaara, P., Ehn, M., Kulmala, M., Tomlinson, J. M., Collins, D. R., Cubison, M. J., Dunlea, E. J., Huffman, J. A., Onasch, T. B., Alfarra, M. R., Williams, P. I., Bower, K., Kondo, Y., Schneider, J., Drewnick, F., Borrmann, S., Weimer, 5 S., Demerjian, K., Salcedo, D., Cottrell, L., Griffin, R., Takami, A., Miyoshi, T., Hatakeyama, S., Shimono, A., Sun, J. Y., Zhang, Y. M., Dzepina, K., Kimmel, J. R., Sueper, D., Jayne, J. T., Herndon, S. C., Trimborn, A. M., Williams, L. R., Wood, E. C., Middlebrook, A. M., Kolb, C. E., Baltensperger, U., and Worsnop, D. R.: Evolution of organic aerosols in the atmosphere, Science, 326, 1525-1529, 2009.

Kleinman, L., Lee, Y.-N., Springston, S. R., Nunnermacker, L., Zhou, X., Brown, R., Hallock, K., Klotz, P., Leahy, D., Lee, J. H., Newman, L.: Ozone formation at a rural site in the southeastern United States, J. Geophys. Res., 99, 3469-3482, 1994.

Kulmala, M., Asmi, A., Lappalainen, H. K., Baltensperger, U., Brenguier, J.-L., Facchini, M. C., Hansson, H.-C., Hov, Ø., O’Dowd, C. D., Pöschl, U., Wiedensohler, A., Boers, R., Boucher, O., de Leeuw, G., Denier van der Gon, H. A. C., Feichter, J., Krejci, R., Laj, P., Lihavainen, H., Lohmann, U., McFiggans, G., Mentel, T., Pilinis, C., Riipinen, I., Schulz, M., Stohl, A., Swietlicki, E., Vignati, E., Alves, C., Amann, M., Ammann, M., Arabas, S., Artaxo, P., Baars, H., Beddows, D. C. S., Bergström, R., Beukes, J. P., Bilde, M., Burkhart, J. F., Canonaco, F., Clegg, S. L., Coe, H., Crumeyrolle, S., D’Anna, B., Decesari, S., Gilardoni, S., Fischer, M., Fjaeraa, A. M., Fountoukis, C., George, C., Gomes, L., Halloran, P., Hamburger, T., Harrison, R. M., Herrmann, H., Hoffmann, T., Hoose, C., Hu, M., Hyvärinen, A., Hõrrak, U., Iinuma, Y., Iversen, T., Josipovic, M., Kanakidou, M., Kiendler-Scharr, A., Kirkevåg, A., Kiss, G., Klimont, Z., Kolmonen, P., Komppula, M., Kristjánsson, J.-E., Laakso, L., Laaksonen, A., Labonnote, L., Lanz, V. A., Lehtinen, K. E. J., Rizzo, L. V., Makkonen, R., Manninen, H. E., McMeeking, G., Merikanto, J., Minikin, A., Mirme, S., Morgan, W. T., Nemitz, E., O’Donnell, D., Panwar, T. S., Pawlowska, H., Petzold, A., Pienaar, J. J., Pio, C., Plass-Duelmer, C., Prévôt, A. S. H., Pryor, S., Reddington, C. L., Roberts, G., Rosenfeld, D., Schwarz, J., Seland, Ø., Sellegri, K., Shen, X. J., Shiraiwa, M., Siebert, H., Sierau, B., Simpson, D., Sun, J. Y., Topping, D., Tunved, P., Vaattovaara, P., Vakkari, V., Veefkind, J. P., Visschedijk, A., Vuollekoski, H., Vuolo, R., Wehner, B., Wildt, J., Woodward, S., Worsnop, D. R., van Zadelhoff, G.-J., Zardini, A. A., Zhang, K., van Zyl, P. G., Kerminen, V.-M., S Carslaw, K., and Pandis, S. N.: General overview: European Integrated project on Aerosol Cloud Climate and Air Quality interactions (EUCAARI) - integrating aerosol research from nano to global scales, Atmos. Chem. Phys., 11, 13061-13143, doi:10.5194/acp11-13061-2011, 2011.

Laborde, M., Crippa, M., Tritscher, T., Jurányi, Z., Decarlo, P. F., Temime-Roussel, B., Marchand, N., Eckhardt, S., Stohl, A., Baltensperger, U., Prévôt, A. S. H., Weingartner, E., and Gysel, 
M.: Black carbon physical properties and mixing state in the European megacity Paris, Atmos. Chem. Phys., 13, 5831-5856, doi:10.5194/acp-13-5831-2013, 2013.

Lanz, V. A., Alfarra, M. R., Baltensperger, U., Buchmann, B., Hueglin, C., and Prévôt, A. S. H.: Source apportionment of submicron organic aerosols at an urban site by factor analytical modelling of aerosol mass spectra, Atmos. Chem. Phys., 7, 1503-1522, doi:10.5194/acp-7-1503-2007, 2007.

Larssen, S., Sluyter, R., and Helmis, C.: Criteria for EUROAIRNET, the EEA Air Quality Monitoring and Information Network, Technical Report No.12, European Environmental Agency, Copenhagen, 1999.

Laskin, A., Laskin, J., and Nizkorodov, S. A.: Mass spectrometric approaches for chemical characterisation of atmospheric aerosols: critical review of the most recent advances, Environ. Chem., 9, 163-189, 2012.

Lin, C.-J.: Projected gradient methods for non-negative matrix factorization, Neural Comput., 19, 2756-2779, doi:10.1162/neco.2007.19.10.2756, 2007.

Liu, D., Allan, J. D., Young, D. E., Coe, H., Beddows, D., Fleming, Z. L., Flynn, M. J., Gallagher, M. W., Harrison, R. M., Lee, J., Prevot, A. S. H., Taylor, J. W., Yin, J., Williams, P. I., and Zotter, P.: Size distribution, mixing state and source apportionment of black carbon aerosol in London during wintertime, Atmos. Chem. Phys., 14, 10061-10084, doi:10.5194/acp14-10061-2014, 2014.

Matta, E., Facchini, M. C., Decesari, S., Mircea, M., Cavalli, F., Fuzzi, S., Putaud, J.-P., and Dell'Acqua, A.: Mass closure on the chemical species in size-segregated atmospheric aerosol collected in an urban area of the Po Valley, Italy, Atmos. Chem. Phys., 3, 623-637, doi:10.5194/acp-3-623-2003, 2003.

McLafferty, F. W.: Interpretation of Mass Spectra, 3rd Ed., 303 pp., University Science Books, Sausalito (CA), USA, 1993.

Middlebrook, A. M., Bahreini, R., Jimenez, J. L., and Canagaratna, M. R.: Evaluation of composition-dependent collection efficiencies for the aerodyne aerosol mass spectrometer using field data, Aerosol Sci. Tech., 46, 258-271, 2012.

Mohr, C., DeCarlo, P. F., Heringa, M. F., Chirico, R., Slowik, J. G., Richter, R., Reche, C., Alastuey, A., Querol, X., Seco, R., Peñuelas, J., Jiménez, J. L., Crippa, M., Zimmermann, R., Baltensperger, U., and Prévôt, A. S. H.: Identification and quantification of organic aerosol from cooking and other sources in Barcelona using aerosol mass spectrometer data, Atmos. Chem. Phys., 12, 1649-1665, doi:10.5194/acp-12-1649-2012, 2012.

Moffet, R. C. and Prather, K. A.: In-situ measurements of the mixing state and optical properties of soot with implications for radiative forcing estimates, Proc. Natl. Acad. Sci. U. S. A., 106, 11872-11877, 2009.

Neubauer, K. R., Johnston, M. V., and Wexler, A. S.: Humidity effects on the mass spectra of single aerosol particles, Atmos. Environ., 32, 2521-2529, 1998.

Onasch, T. B., Trimborn, A., Fortner, E. C., Jayne, J. T., Kok, G. L., Williams, L. R., Davidovits, P., and Worsnop, D. R.: Soot particle aerosol mass spectrometer: development, validation, and initial application, Aerosol Sci. Tech., 46, 804-817, 2012.

Paatero, P. and Tapper, U.: Positive Matrix Factorization: a nonnegative factor model with optimal utilization of error estimates of data values, Environmetrics, 5, 111-126, doi:10.1002/env.3170050203, 1994.
Paglione, M., Saarikoski, S., Carbone, S., Hillamo, R., Facchini, M. C., Finessi, E., Giulianelli, L., Carbone, C., Fuzzi, S., Moretti, F., Tagliavini, E., Swietlicki, E., Eriksson Stenström, K., Prévôt, A. S. H., Massoli, P., Canaragatna, M., Worsnop, D., and Decesari, S.: Primary and secondary biomass burning aerosols determined by proton nuclear magnetic resonance $\left({ }^{1} \mathrm{H}-\mathrm{NMR}\right)$ spectroscopy during the 2008 EUCAARI campaign in the Po Valley (Italy), Atmos. Chem. Phys., 14, 5089-5110, doi:10.5194/acp-14-50892014, 2014.

Plass-Dülmer, C., Elste, T., Paasonen, P., and Petäjä, T.: Sulfuric Acid Measurements by CIMS - Uncertainties and Consistency between Various Data Sets, Poster presentation at EGU General Assembly 2011, Vienna, available at: http://presentations. copernicus.org/EGU2011-11691_presentation.ppt (last access: 1 April 2014), 2011.

Pope, F. D., Tong, H.-J., Dennis-Smither, B. J., Griffiths, P. T., Clegg, S. L., Reid, J. P., and Cox, R. A.: Studies of Single Aerosol Particles Containing Malonic Acid, Glutaric Acid, and Their Mixtures with Sodium Chloride. II. Liquid-State Vapor Pressures of the Acids, J. Phys. Chem. A., 114, 10156-10165, doi:10.1021/jp1052979, 2010.

Rinaldi, M., Emblico, L., Decesari, S., Fuzzi, S., Facchini, M. C., and Librando, V.: Chemical characterization and source apportionment of size-segregated aerosol collected at an urban site in Sicily, Water Air Soil Poll., 185, 311-321, 2007.

Rohrer, F. and Berresheim, H.: Strong correlation between levels of tropospheric hydroxyl radicals and solar ultraviolet radiation, Nature, 442, 7099, 184-187, doi:10.1038/nature04924, 2006.

Saarikoski, S., Carbone, S., Decesari, S., Giulianelli, L., Angelini, F., Canagaratna, M., Ng, N. L., Trimborn, A., Facchini, M. C., Fuzzi, S., Hillamo, R., and Worsnop, D.: Chemical characterization of springtime submicrometer aerosol in Po Valley, Italy, Atmos. Chem. Phys., 12, 8401-8421, doi:10.5194/acp-12-84012012, 2012.

Shiraiwa, M., Kondo, Y., Moteki, N., Takegawa, N., Miyazaki, Y., and Blake, D. R.: Evolution of mixing state of black carbon in polluted air from Tokyo, Geophys. Res. Lett., 34, L16803, doi:10.1029/2007GL029819, 2007.

Song, X. H., Hopke, P. K., Fergenson, D. P., and Prather, K. A.: Classification of single particles analyzed by ATOFMS using an artificial neural network, ART-2A, Anal. Chem., 71, 860-865, 1999.

Spencer, M. T., Shields, L. G., and Prather, K. A.: Simultaneous measurement of the effective density and chemical composition of ambient aerosol particles, Environ. Sci. Technol., 41, 1303-1309, 2007.

Tauler, R.: Multivariate curve resolution applied to second order data, Chemometr. Intell. Lab., 30, 133-146, doi:10.1016/01697439(95)00047-X, 1995.

Ulbrich, I. M., Canagaratna, M. R., Zhang, Q., Worsnop, D. R., and Jimenez, J. L.: Interpretation of organic components from Positive Matrix Factorization of aerosol mass spectrometric data, Atmos. Chem. Phys., 9, 2891-2918, doi:10.5194/acp-9-2891-2009, 2009.

Virkkula, A., Ahlquist, N. C., Covert, D. S., Arnott, W. P., Sheridan, P. J., Quinn, P. K., and Coffman, D. J.: Modification, calibration and a field test of an instrument for measuring light absorption by particles, Aerosol Sci. Tech., 39, 68-83, 2005. 
Williams, B. J., Goldstein, A. H., Kreisberg, N. M., and Hering, S. V.: An in-situ instrument for speciated organic composition of atmospheric aerosols: thermal desorption Aerosol GC/MSFID (TAG), Aerosol Sci. Technol., 40, 627-638, 2006.

Williams, B. J., Goldstein, A. H., Kreisberg, N. M., Hering, S. V., Worsnop, D. R., Ulbrich, I. M., Docherty, K. S., and Jimenez, J. L.: Major components of atmospheric organic aerosol in southern California as determined by hourly measurements of source marker compounds, Atmos. Chem. Phys., 10, 11577-11603, doi:10.5194/acp-10-11577-2010, 2010.

Williams, B. J., Jayne, J. T., Lambe, A. T., Hohaus, T., Kimmel, J. R., Sueper, D., Brooks, W., Williams, L. R., Trimborn, A. M., Martinez, R. E., Hayes, P. L., Jimenez, J. L., Kreisberg, N. M., Hering, S. V., Worton, D. R., Goldstein, A. H., and Worsnop, D. R.: The first combined thermal desorption aerosol gas chromatograph - aerosol mass spectrometer (TAG-AMS), Aerosol Sci. Technol, 48, 358-370, 2014.

Wood, E. C., Canagaratna, M. R., Herndon, S. C., Onasch, T. B., Kolb, C. E., Worsnop, D. R., Kroll, J. H., Knighton, W. B., Seila, R., Zavala, M., Molina, L. T., DeCarlo, P. F., Jimenez, J. L., Weinheimer, A. J., Knapp, D. J., Jobson, B. T., Stutz, J., Kuster, W. C., and Williams, E. J.: Investigation of the correlation between odd oxygen and secondary organic aerosol in Mexico City and Houston, Atmos. Chem. Phys., 10, 8947-8968, doi:10.5194/acp-10-8947-2010, 2010.
Young, D. E., Allan, J. D., Williams, P. I., Green, D. C., Harrison, R. M., Yin, J., Flynn, M. J., Gallagher, M. W., and Coe, H.: Investigating the two-component model of solid fuel organic aerosol in London: processes, $\mathrm{PM}_{1}$ contributions, and seasonality, Atmos. Chem. Phys. Discuss., 14, 20845-20882, doi:10.5194/acpd-1420845-2014, 2014.

Zanatta, M., Cavalli, F., Gysel, M., Weingartner, E., Baltensperger, U., and Laj, P.: Black carbon (BC) absorbing properties over Europe, in preparation, 2014.

Zhang, Y., Williams, B. J., Goldstein, A. H., Ulbrich, I. M., Docherty, K., and Jimenez, J. L.: A technique for rapid gas chromatography analysis applied to ambient organic aerosol measurements from the thermal desorption aerosol gas chromatograph (TAG), Aerosol Sci. Technol., 48, 1166-1182, doi:10.1080/02786826.2014.967832, 2014. 